\title{
LEVEL II SCOUR ANALYSIS FOR BRIDGE 9 (JAY-VT02420009) ON VERMONT HIGHWAY 242, CROSSING THE JAY BRANCH OF THE MISSISQUOI RIVER, JAY, VERMONT
}

U.S. Geological Survey

Open-File Report 96-750

Prepared in cooperation with

VERMONT AGENCY OF TRANSPORTATION

and

FEDERAL HIGHWAY ADMINISTRATION

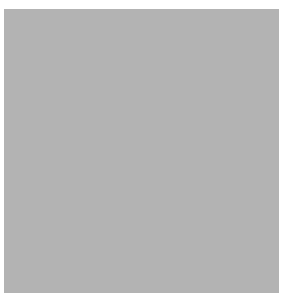


LEVEL II SCOUR ANALYSIS FOR

BRIDGE 9 (JAY-VT02420009) ON

VERMONT HIGHWAY 242, CROSSING THE

JAY BRANCH OF THE MISSISQUOI RIVER,

JAY, VERMONT

By ROBERT H. FLYNN AND MICHAEL A. IVANOFF

U.S. Geological Survey

Open-File Report 96-750

Prepared in cooperation with

VERMONT AGENCY OF TRANSPORTATION

and

FEDERAL HIGHWAY ADMINISTRATION

Pembroke, New Hampshire 


\title{
U.S. DEPARTMENT OF THE INTERIOR BRUCE BABBITT, Secretary
}

\author{
U.S. GEOLOGICAL SURVEY \\ Gordon P. Eaton, Director
}

For additional information write to:

District Chief

U.S. Geological Survey 361 Commerce Way

Pembroke, NH 03275-3718
Copies of this report may be purchased from:

U.S. Geological Survey

Branch of Information Services

Open-File Reports Unit

Box 25286

Denver, CO 80225-0286 


\section{CONTENTS}

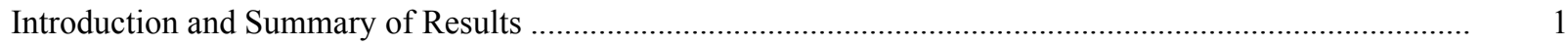

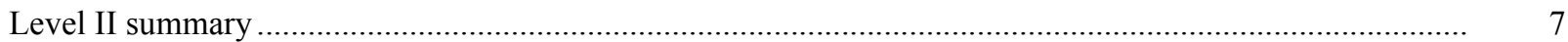

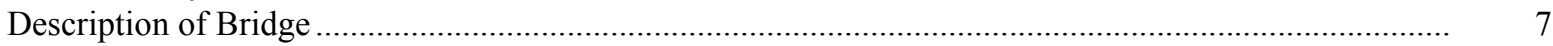

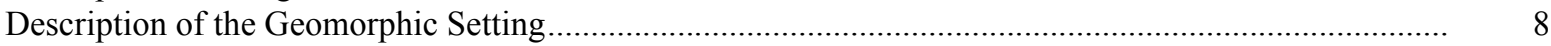

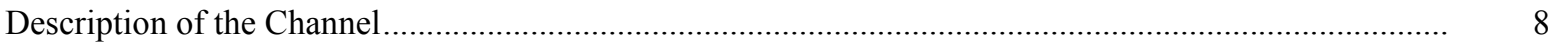

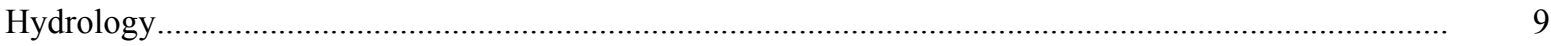

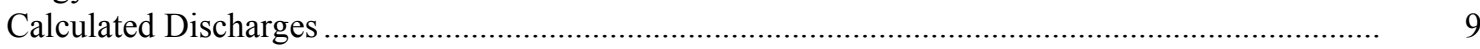

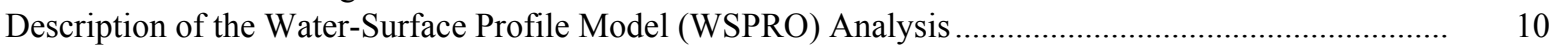

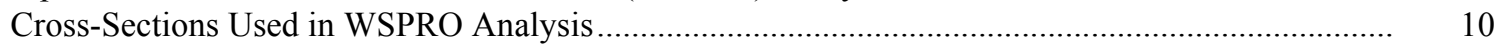

Data and Assumptions Used in WSPRO Model ...................................................................... 11

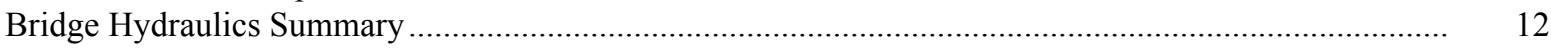

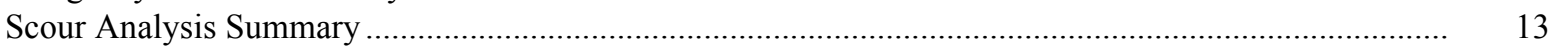

Special Conditions or Assumptions Made in Scour Analysis ...................................................... 13

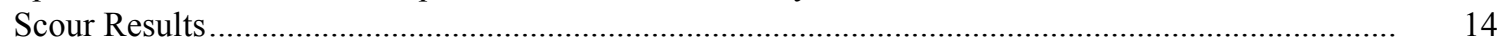

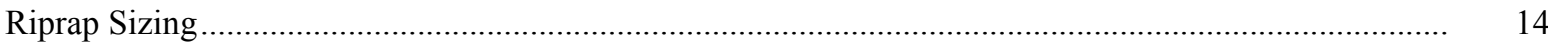

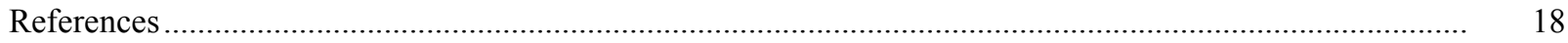

Appendixes:

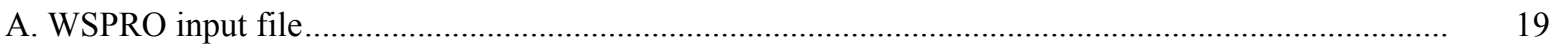

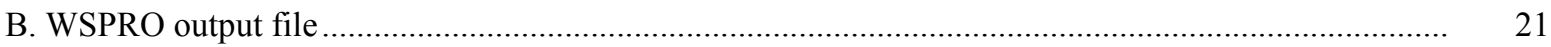

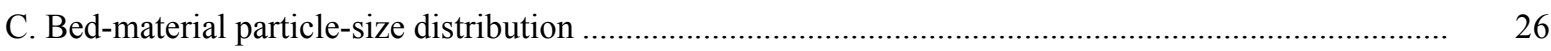

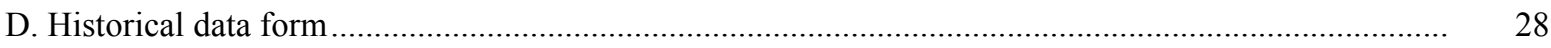

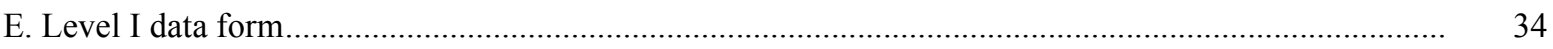

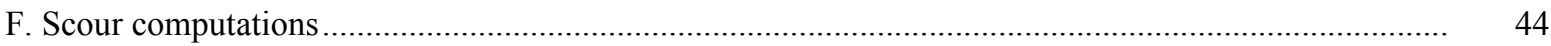

\section{FIGURES}

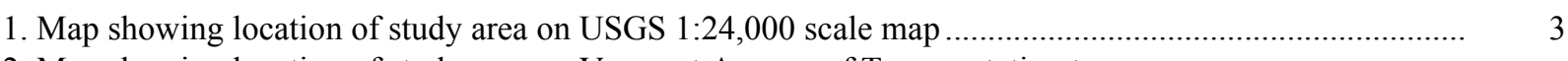

2. Map showing location of study area on Vermont Agency of Transportation town

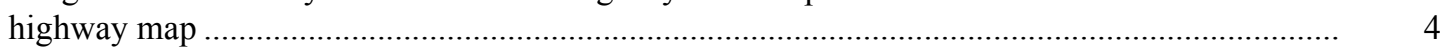

3. Structure JAY-VT02420009 viewed from upstream (June 6, 1995) ....................................................... 5

4. Downstream channel viewed from structure JAY-VT02420009 (June 6, 1995). ................................. 5

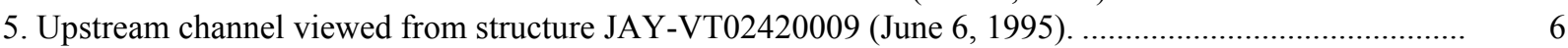

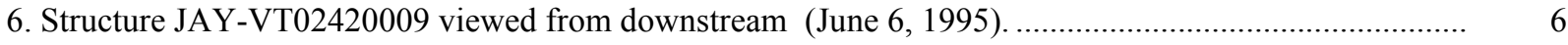

7. Water-surface profiles for the 100- and 500-year discharges at structure
JAY-VT02420009 on Vermont Highway 242, crossing the Jay Branch of the Missisquoi River, Jay, Vermont.

8. Scour elevations for the 100- and 500-year discharges at structure

JAY-VT02420009 on Vermont Highway 242, crossing the Jay Branch of the Missisquoi River, Jay, Vermont.

\section{TABLES}

1. Remaining footing/pile depth at abutments for the 100-year discharge at structure

JAY-VT02420009 on Vermont Highway 242, crossing the Jay Branch of the Missisquoi River,

Jay, Vermont

2. Remaining footing/pile depth at abutments for the 500-year discharge at structure

JAY-VT02420009 on Vermont Highway 242, crossing the Jay Branch of the Missisquoi River, Jay, Vermont 


\begin{tabular}{|c|c|c|}
\hline Multiply & By & To obtain \\
\hline \multicolumn{3}{|c|}{ Length } \\
\hline inch (in.) & 25.4 & millimeter (mm) \\
\hline foot $(\mathrm{ft})$ & 0.3048 & meter $(\mathrm{m})$ \\
\hline mile (mi) & 1.609 & kilometer (km) \\
\hline \multicolumn{3}{|c|}{ Slope } \\
\hline foot per mile ( $\mathrm{ft} / \mathrm{mi})$ & 0.1894 & meter per kilometer $(\mathrm{m} / \mathrm{km})$ \\
\hline \multicolumn{3}{|c|}{ Area } \\
\hline square mile $\left(\mathrm{mi}^{2}\right)$ & 2.590 & square kilometer $\left(\mathrm{km}^{2}\right)$ \\
\hline \multicolumn{3}{|c|}{ Volume } \\
\hline cubic foot $\left(\mathrm{ft}^{3}\right)$ & $\begin{array}{l}0.02832 \\
\text { Velocity and Flow }\end{array}$ & cubic meter $\left(\mathrm{m}^{3}\right)$ \\
\hline foot per second (ft/s) & 0.3048 & meter per second $(\mathrm{m} / \mathrm{s})$ \\
\hline cubic foot per second $\left(\mathrm{ft}^{3} / \mathrm{s}\right)$ & 0.02832 & cubic meter per second $\left(\mathrm{m}^{3} / \mathrm{s}\right)$ \\
\hline $\begin{array}{l}\text { cubic foot per second per } \\
\text { square mile } \\
{\left[\left(\mathrm{ft}^{3} / \mathrm{s}\right) / \mathrm{mi}^{2}\right]}\end{array}$ & 0.01093 & $\begin{array}{l}\text { cubic meter per } \\
\text { second per square } \\
\text { kilometer }\left[\left(\mathrm{m}^{3} / \mathrm{s}\right) / \mathrm{km}^{2}\right]\end{array}$ \\
\hline
\end{tabular}

OTHER ABBREVIATIONS

$\begin{array}{lrlr}\mathrm{BF} & \text { bank full } & \text { LWW } & \text { left wingwall } \\ \mathrm{cfs} & \text { cubic feet per second } & \text { MC } & \text { main channel } \\ \mathrm{D}_{50} & \text { median diameter of bed material } & \text { RAB } & \text { right abutment } \\ \mathrm{DS} & \text { downstream } & \text { RABUT } & \text { face of right abutment } \\ \mathrm{elev} & \text { elevation } & \text { RB } & \text { right bank } \\ \mathrm{f} / \mathrm{p} & \text { flood plain } & \text { ROB } & \text { right overbank } \\ \mathrm{ft} & \text { square feet } & \text { RWW } & \text { right wingwall } \\ \mathrm{ft} / \mathrm{ft} & \text { feet per foot } & \text { TH } & \text { town highway } \\ \mathrm{JCT} & \text { junction } & \text { UB } & \text { under bridge } \\ \mathrm{LAB} & \text { left abutment } & \text { US } & \text { upstream } \\ \mathrm{LABUT} & \text { face of left abutment } & \text { USGS } & \text { United States Geological Survey } \\ \text { LB } & \text { left bank } & \text { VTAOT Vermont Agency of Transportation } \\ \text { LOB } & \text { left overbank } & \text { WSPRO } & \text { water-surface profile model }\end{array}$

In this report, the words "right" and "left" refer to directions that would be reported by an observer facing downstream. Sea level: In this report, "sea level" refers to the National Geodetic Vertical Datum of 1929-- a geodetic datum derived from a general adjustment of the first-order level nets of the United States and Canada, formerly called Sea Level Datum of 1929.

In the appendices, the above abbreviations may be combined. For example, USLB would represent upstream left bank. 


\title{
LEVEL II SCOUR ANALYSIS FOR BRIDGE 9 (JAY-VT02420009) ON VERMONT HIGHWAY 242, CROSSING THE JAY BRANCH OF THE MISSISQUOI RIVER, JAY, VERMONT
}

\author{
By Robert H. Flynn and Michael A. Ivanoff \\ INTRODUCTION AND SUMMARY OF RESULTS
}

This report provides the results of a detailed Level II analysis of scour potential at structure JAY-VT02420009 on Vermont highway 242 crossing the the Jay Branch of the Missisquoi River, Jay, Vermont (figures 1-8). A Level II study is a basic engineering analysis of the site, including a quantitative analysis of stream stability and scour (U.S. Department of Transportation, 1993). Results of a Level I scour investigation also are included in Appendix E of this report. A Level I study provides a qualitative geomorphic characterization of the study site. Information on the bridge, gleaned from Vermont Agency of Transportation (VTAOT) files, was compiled prior to conducting Level I and Level II analyses and is found in Appendix D.

The site is in the Green Mountain section of the New England physiographic province of northern Vermont in the town of Jay. The $4.36-\mathrm{mi}^{2}$ drainage area is in a predominantly rural and forested basin. In the vicinity of the study site, the surface cover is primarily forest and brush except for the downstream left overbank which is grass.

In the study area, the the Jay Branch of the Missisquoi River has an incised, sinuous channel with a slope of approximately $0.021 \mathrm{ft} / \mathrm{ft}$, an average channel top width of $38 \mathrm{ft}$ and an average channel depth of $5 \mathrm{ft}$. A Level I visual inspection at the site indicates that the predominant channel bed material is cobble and boulder with gravel. Results of a pebble count indicate that the predominant channnel bed material is a very coarse gravel with a median grain size $\left(\mathrm{D}_{50}\right)$ of $41.7 \mathrm{~mm}(0.1369 \mathrm{ft})$. The geomorphic assessment at the time of the Level I and Level II site visit on June 6, 1995, indicated that the reach was stable.

The Vermont highway 242 crossing of the the Jay Branch of the Missisquoi River is a 60ft-long, two-lane bridge consisting of one 55-foot steel-beam span (Vermont Agency of Transportation, written communication, March 6, 1995). The bridge is supported by vertical, concrete abutments with wingwalls. The channel is skewed approximately 60 degrees to the opening while the opening-skew-to-roadway is 45 degrees.

The scour protection measures at the site included type- 2 stone fill (less than 36 inches diameter) at the upstream right wingwall, the downstream left and right wingwalls and the upstream end of the left abutment. Type-1 stone fill (less than 12 inches) was along the upstream end of the right abutment. Type-4 stone fill (less than 64 inches) was along the upstream left wingwall. Additional details describing conditions at the site are included in the Level II Summary and Appendices D and E. 
Scour depths and rock rip-rap sizes were computed using the general guidelines described in Hydraulic Engineering Circular 18 (Richardson and others, 1995). Total scour at a highway crossing is comprised of three components: 1) long-term streambed degradation; 2) contraction scour (due to accelerated flow caused by a reduction in flow area at a bridge) and; 3) local scour (caused by accelerated flow around piers and abutments). Total scour is the sum of the three components. Equations are available to compute depths for contraction and local scour and a summary of the results of these computations follows.

Contraction scour for all modelled flows ranged from 0.0 to $0.6 \mathrm{ft}$. The worst-case contraction scour occurred at the 100-year discharge. Abutment scour ranged from 0.8 to $5.6 \mathrm{ft}$. The worst-case abutment scour occurred at the 500-year discharge. Additional information on scour depths and depths to armoring are included in the section titled "Scour Results". Scoured streambed elevations, based on the calculated scour depths, are presented in tables 1 and 2. A cross-section of the scour computed at the bridge is presented in figure 8. Scour depths were calculated assuming an infinite depth of erosive material and a homogeneous particle-size distribution.

It is generally accepted that the Froehlich equation (abutment scour) gives "excessively conservative estimates of scour depths" (Richardson and others, 1995, p. 47). Usually, computed scour depths are evaluated in combination with other information including (but not limited to) historical performance during flood events, the geomorphic stability assessment, existing scour protection measures, and the results of the hydraulic analyses. Therefore, scour depths adopted by VTAOT may differ from the computed values documented herein. 


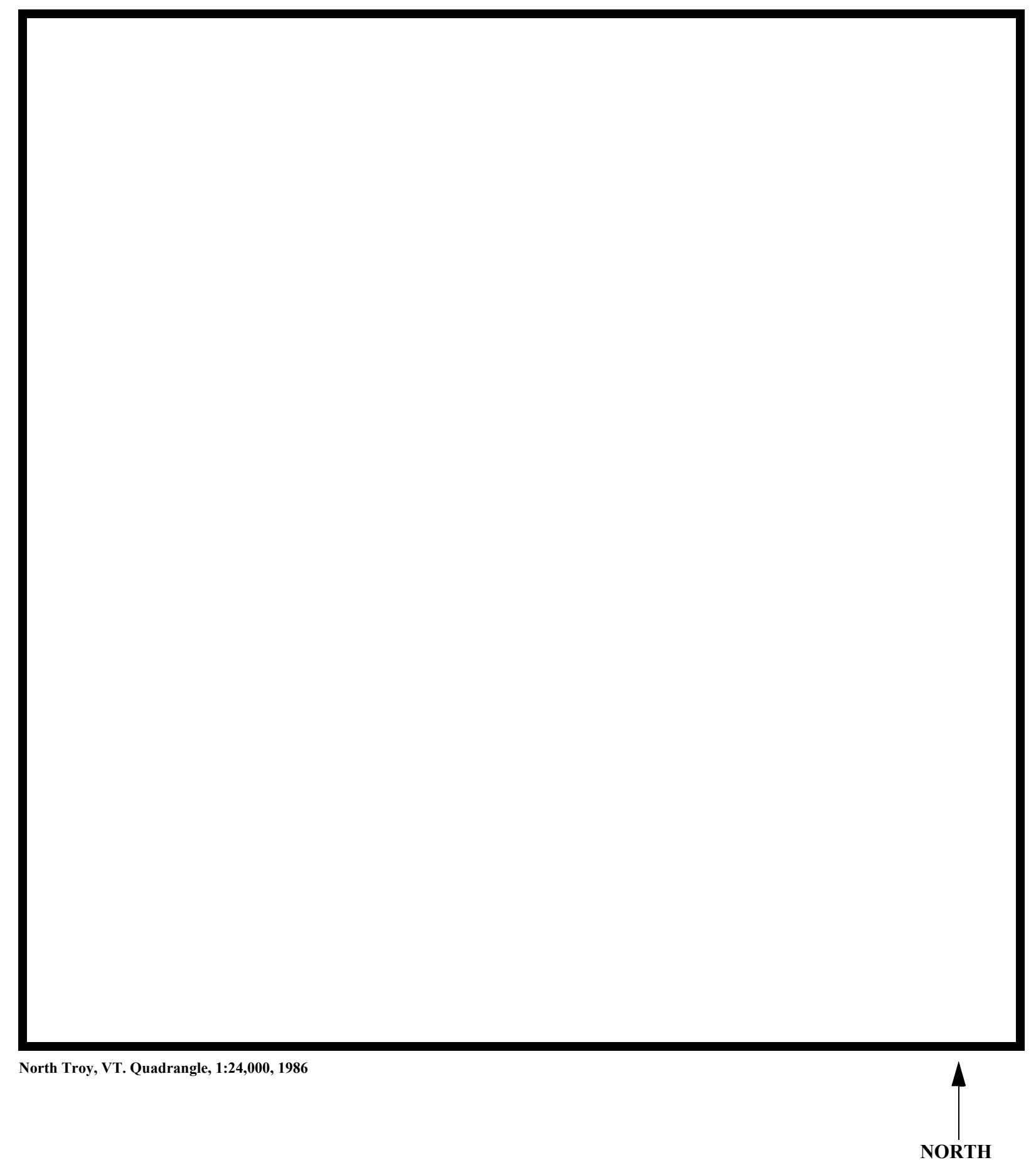

Figure 1. Location of study area on USGS 1:24,000 scale map. 
Figure 2. Location of study area on Vermont Agency of Transportation town highway map. 

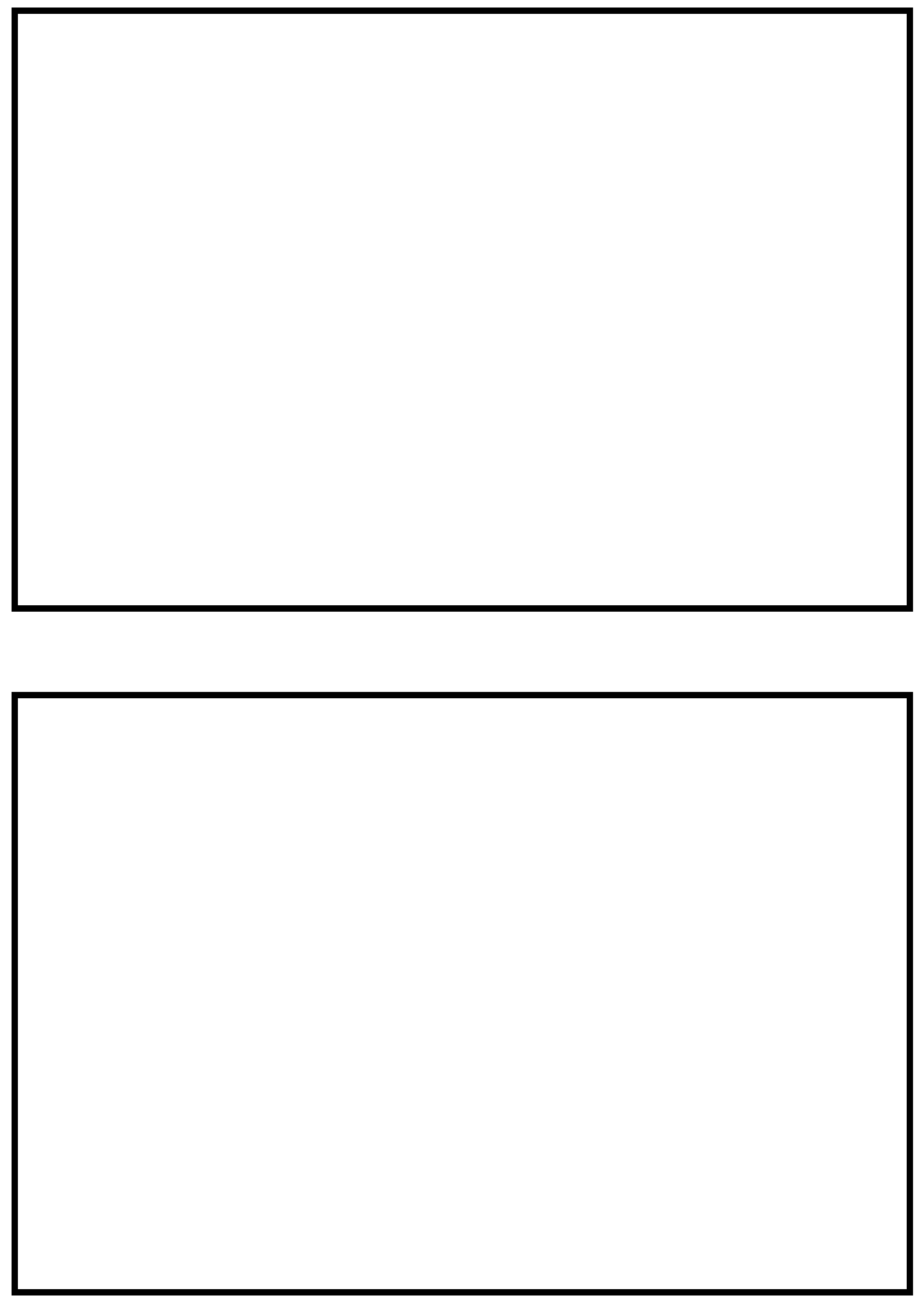

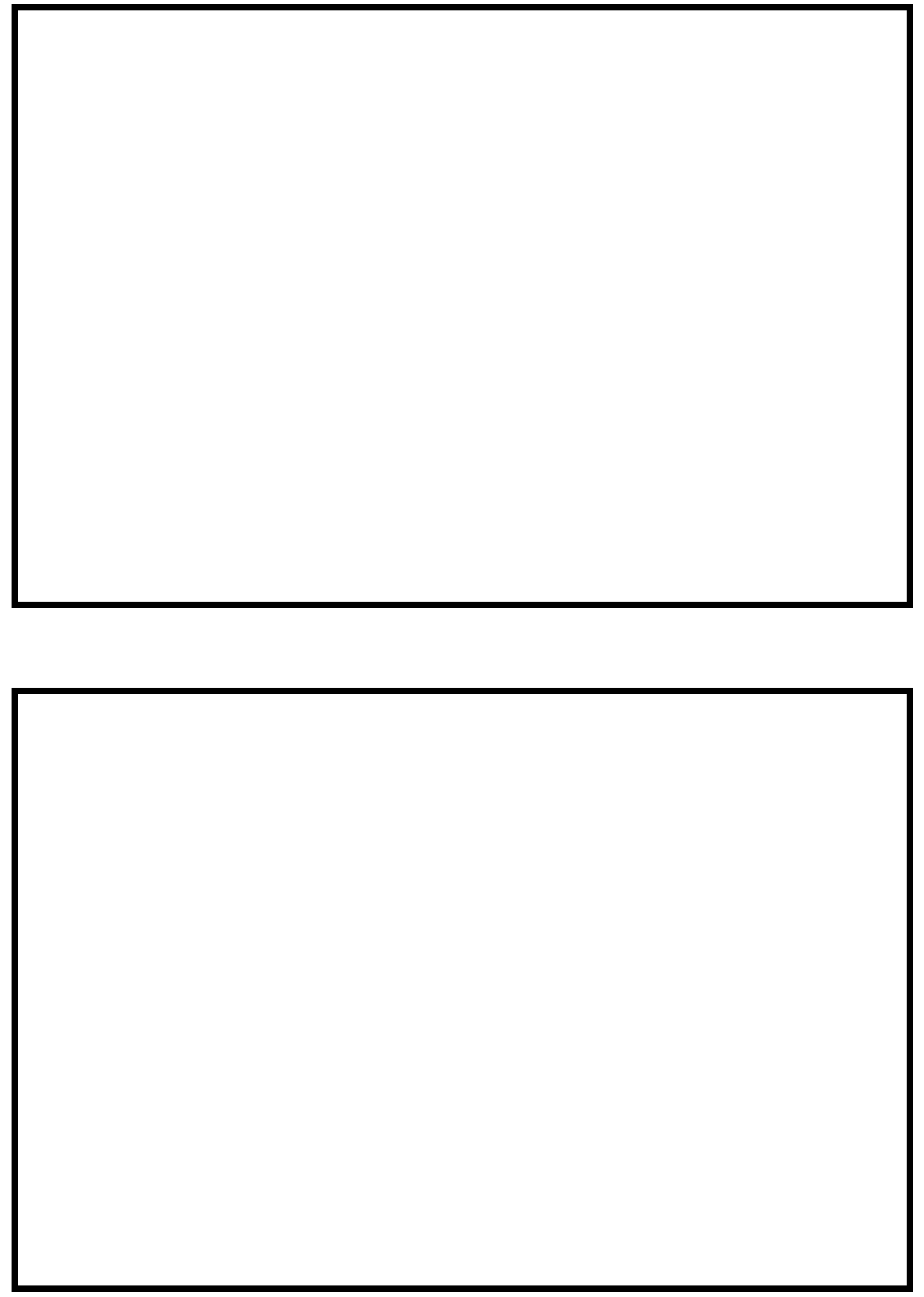


\section{LEVEL II SUMMARY}

\begin{tabular}{llllll} 
& Structure Number & JAY-VT02420009 & Stream & \multicolumn{3}{c}{ Jay Branch of Missisquoi River } \\
& Road & VT 242 & District & 09 \\
County & Orleans & Roal &
\end{tabular}

\section{Description of Bridge}

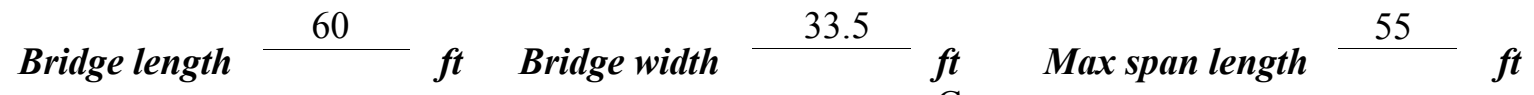
Alignment of bridge to road (on curve or straight) Vertical Abutment type

Stone fill on abutment?
Type-2, at the upstream right wingwall, downstream right wingwall, downstream left wingwall and left abutment; type-1, at the right abutment; and type-4, at the upstream left wingwall. Protection is sparse along abutments.

Abutments and wingwalls are concrete. No scour

holes were observed during the Level I assessment.

\section{0}

Is bridge skewed to flood flow according to Yes 'survey? Angle

There is a severe channel bend at the upstream channel reach. Channel at approach is parallel to

VT 242 and then downstream is nearly perpendicular to the bridge.

Debris accumulation on bridge at time of Level I or Level II site visit:

\begin{tabular}{|c|c|c|c|}
\hline & $\begin{array}{c}\text { Date of insnortion } \\
06 / 06 / 95\end{array}$ & $\begin{array}{l}\text { Percent of almmual } \\
\text { blocked inortzontatly }\end{array}$ & $\begin{array}{l}\text { Percent of } 0 \\
\text { blocked verticatty }\end{array}$ \\
\hline vel I & $06 / 06 / 95$ & 0 & 0 \\
\hline & \multicolumn{2}{|c|}{ Low. Stable banks. } & \\
\hline
\end{tabular}

Potential for debris

Abutments are skewed to flow (06/06/95).

Doscriho anv fonturos noar ar at tho hridoo that mav, affort flou, (includo ahsorvation dato) 


\section{Description of the Geomorphic Setting}

General topography The channel is located within a moderate relief valley setting with a narrow flood plain.

Geomorphic conditions at bridge site: downstream (DS), upstream (US)

Date of inspection $\quad 06 / 06 / 95$

DS left: $\quad$ Steep channel bank to a moderately sloped overbank along Vt 242.

DS right: $\quad$ Moderately sloped bank and overbank.

US left: $\quad$ Steep channel bank and overbank.

US right: $\quad$ Steep channel bank and overbank

\section{Description of the Channel}

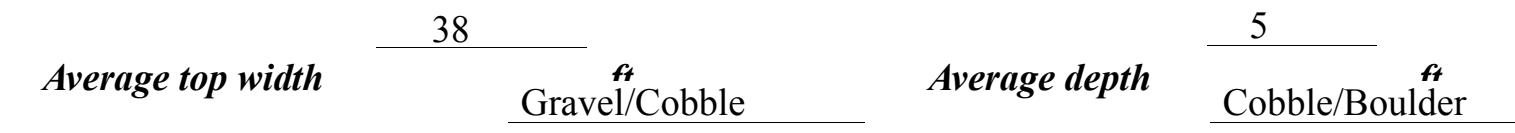

Predominant bed material Bank material Sinuous but stable

with semi-alluvial to non-alluvial channel boundaries and a very narrow flood plain.

$06 / 06 / 95$

Vegetative co ${ }^{1}$ Cut grass and a few trees

DS left: $\quad$ Trees and brush

DS right: $\quad$ Trees and brush

US left: $\quad$ Grass on bank, Vt 242 (paved road) and then trees along far side of road..

US right: $\quad$ Y

Do banks appear stable? -

y mus, ме

date of observatton.

06/95 noted a point bar with large boulders along the upstream left bank. Describe any obstructions in channel and date of observation. 


\title{
Hydrology
}

Drainage area $\quad 4.36 \boldsymbol{m i}^{2}$

Percentage of drainage area in physiographic provinces: (approximate)

Physiographic province/section

New England/Green Mountain
Percent of drainage area 100

\begin{abstract}
Is drainage area considered rural or urban?
Rural None.

urbanization:-

Describe any significant
\end{abstract}

Is there a USGS gage on the stream of interest?

No

USGS gage description

USGS gage number

Gage drainage area $\mathrm{mi}^{2}$ $--$

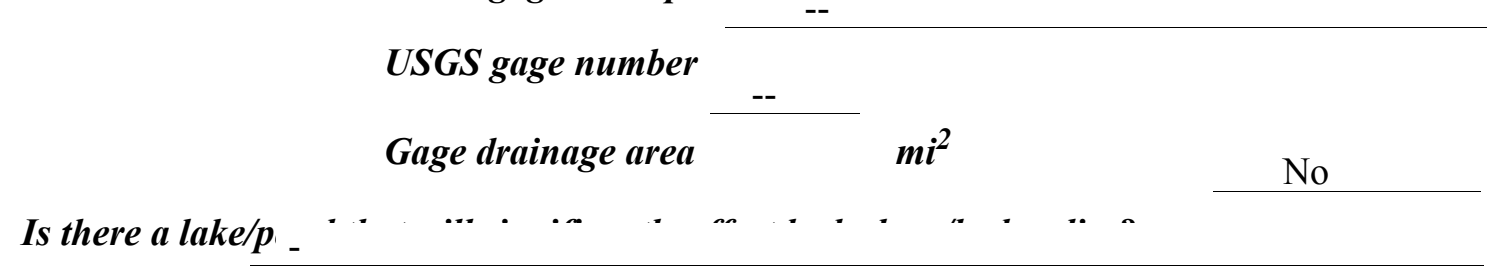

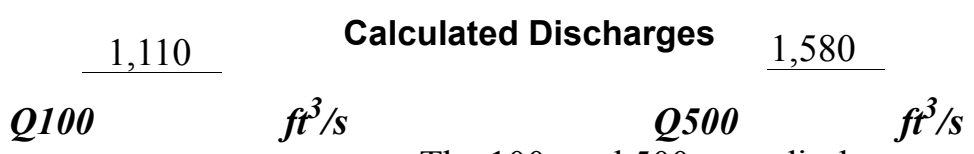

The 100- and 500-year discharges are based on a

drainage area relationship [(4.3/4.36)exp 0.7] with bridge number 11 in Jay. Bridge number 11 crosses an unnamed tributary to the Jay Branch of the Missisquoi River downstream of this site and has flood frequency estimates available from the VTAOT database (VTAOT, written communication, May, 1995). The basin characteristics of bridge number 11 are similar to Jay bridge number 9 . The drainage area above bridge number 11 is 4.30 square miles. 


\section{Description of the Water-Surface Profile Model (WSPRO) Analysis}

Datum for WSPRO analysis (USGS survey, sea level, VTAOT plans)

USGS survey

Datum tie between USGS survey and VTAOT plans

Subtract 396.5 feet from arbitrary

survey datum to obtain VTAOT plans datum.

Description of reference marks used to determine USGS datum. $\quad$ RM1 is a chiseled X on

top of the US end of the right abutment (elev. $502.08 \mathrm{ft}$, arbitrary survey datum).

RM2 is a chiseled X on top of the DS end of the left abutment (elev. $502.70 \mathrm{ft}$, arbitrary survey

datum).

Cross-Sections Used in WSPRO Analysis

\begin{tabular}{|c|c|c|c|}
\hline${ }^{1}$ Cross-section & $\begin{array}{c}\text { Section } \\
\text { Reference } \\
\text { Distance } \\
\text { (SRD) in feet }\end{array}$ & $\begin{array}{c}{ }^{2} \text { Cross-section } \\
\text { development }\end{array}$ & Comments \\
\hline EXITX & -50 & 1 & Exit section \\
\hline FULLV & 0 & 2 & $\begin{array}{l}\text { Downstream Full-valley } \\
\text { section (Templated from } \\
\text { EXITX) }\end{array}$ \\
\hline BRIDG & 0 & 1 & Bridge section \\
\hline RDWAY & 26 & 1 & Road Grade section \\
\hline APPRO & 89 & 2 & $\begin{array}{l}\text { Modelled Approach sec- } \\
\text { tion (Templated from } \\
\text { APTEM) }\end{array}$ \\
\hline APTEM & 137 & 1 & $\begin{array}{l}\text { Approach section as sur- } \\
\text { veyed (Used as a tem- } \\
\text { plate) }\end{array}$ \\
\hline
\end{tabular}

${ }^{1}$ For location of cross-sections see plan-view sketch included with Level I field form, Appendix E.

For more detail on how cross-sections were developed see WSPRO input file. 


\section{Data and Assumptions Used in WSPRO Model}

Hydraulic analyses of the reach were done by use of the Federal Highway Administration's WSPRO step-backwater computer program (Shearman and others, 1986, and Shearman, 1990). The analyses reported herein reflect conditions existing at the site at the time of the study. Furthermore, in the development of the model it was necessary to assume no accumulation of debris or ice at the site. Results of the hydraulic model are presented in the Bridge Hydraulic Summary, Appendix B, and figure 7.

Channel roughness factors (Manning's “ $n$ ”) used in the hydraulic model were estimated using field inspections at each cross section following the general guidelines described by Arcement and Schneider (1989). Final adjustments to the values were made during the modelling of the reach. Channel " $\mathrm{n}$ " values for the reach ranged from 0.055 to 0.065 , and overbank " $\mathrm{n}$ " values ranged from 0.035 to 0.080 .

Normal depth at the exit section (EXITX) was assumed as the starting water surface. This depth was computed by use of the slope-conveyance method outlined in the user's manual for WSPRO (Shearman, 1990). The slope used was $0.0210 \mathrm{ft} / \mathrm{ft}$ which was determined from surveyed thalweg and water surface points downstream of the bridge.

The surveyed approach section (APTEM) was moved along the approach channel slope $(0.0279 \mathrm{ft} / \mathrm{ft})$ to establish the modelled approach section (APPRO), one bridge length upstream of the upstream face as recommended by Shearman and others (1986). This approach also provides a consistent method for determining scour variables. 


\section{Bridge Hydraulics Summary}

$\begin{array}{llll}\text { Average bridge embankment elevation } & 503.5 \\ \text { Average low steel elevation } & 498.3 & \boldsymbol{f t}\end{array}$

100-year discharge $\quad 1,110 \quad \mathrm{ft}^{3} / \mathrm{s}$

Water-surface elevation in bridge opening

$495.1 \mathrm{ft}$

Road overtopping? ___ N Discharge over road __ _. , s

Area of flow in bridge opening $\quad 119 \quad \mathrm{ft}^{2}$

Average velocity in bridge opening $\quad 9.4 \quad \mathrm{ft} / \mathrm{s}$

Maximum WSPRO tube velocity at bridge $\quad 11.3 \mathrm{ft} / \mathrm{s}$

Water-surface elevation at Approach section with bridge 497.9

Water-surface elevation at Approach section without bridge $\quad 497.2$

Amount of backwater caused by bridge

0.7 i

500-year discharge $\quad 1,580 \quad \mathrm{ft}^{3} / \mathrm{s}$

Water-surface elevation in bridge opening

$498.4 \mathrm{ft}$

Road overtopping? ___ N Discharge over road $-\ldots \cdot s$

Area of flow in bridge opening $\quad 239 \quad \mathrm{ft}^{2}$

Average velocity in bridge opening $6.7 \mathrm{ft} / \mathrm{s}$

Maximum WSPRO tube velocity at bridge 9.0 _s

Water-surface elevation at Approach section with bridge 499.4

Water-surface elevation at Approach section without bridge $\quad 497.8$

Amount of backwater caused by bridge 1.6 .

Incipient overtopping discharge ___ -- $\mathrm{ft}^{3} / \mathrm{s}$

Water-surface elevation in bridge opening $\quad--\quad t$

Area of flow in bridge opening _ -- $\mathrm{ft}^{2}$

Average velocity in bridge opening ___ $\quad--\quad f t / s$

Maximum WSPRO tube velocity at bridge _-- $f t / s$

Water-surface elevation at Approach section with bridge

Water-surface elevation at Approach section without bridge

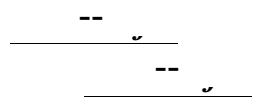

Amount of backwater caused by bridge _ $\quad-{ }_{-}$, $t$ 


\section{Scour Analysis Summary}

\section{Special Conditions or Assumptions Made in Scour Analysis}

Scour depths were computed using the general guidelines described in Hydraulic Engineering Circular 18 (Richardson and others, 1995). Scour depths were calculated assuming an infinite depth of erosive material and a homogeneous particle-size distribution. The results of the scour analysis are presented in tables 1 and 2 and a graph of the scour depths is presented in figure 8 .

Contraction scour for the 100-year discharge was computed by use of Laursen's clear-water contraction scour equation (Richardson and others, 1995, p. 32, equation 20). The 500-year discharge resulted in unsubmerged orifice flow. Contraction scour at bridges with orifice flow is best estimated by use of the Chang pressure-flow scour equation (oral communication, J. Sterling Jones, October 4, 1996). Thus, contraction scour for the 500 -year discharge was computed by use of the Chang pressure flow scour equation (Richarson and others, 1995, p. 145-146). The results of Laursen's contraction scour equation for the 500year event were also computed for comparison and can be found in appendix F.

Since the approach channel is narrower than the bridge section, the abutments do not block flow. This makes computation of abutment scour impossible. Thus, as per the Froehlich equation factor of safety (Richardson and others, 1995, p. 48, equation 28), abutment scour (Ys) was computed as the flow depth (Ya) at the abutment (toe).

Scouring of the streambed along the right abutment footing was reported during a structural inspection conducted by the VTAOT on 10/19/93. The scour was reported to be approximately "three feet below the top of the original footing and roughly a foot below the newer upstream section footing". This scour was not observed during the level II scour analysis of 06/06/95. 


\section{Scour Results}

\section{0-yr discharge 500-yr discharge}

Contraction scour:

(Scour depths in feet)

Main channel

Live-bed scour

Clear-water scour

Depth to armoring

Left overbank

Right overbank

Local scour:

Abutment scour

Left abutment

2.2

5.6

0.8

$4.2-$

Right abutment

Pier scour

Pier 1

Pier 2

Pier 3

\section{Abutments:}

Left abutment

Right abutment

Piers:

Pier 1

Pier 2

Incipient overtopping discharge 


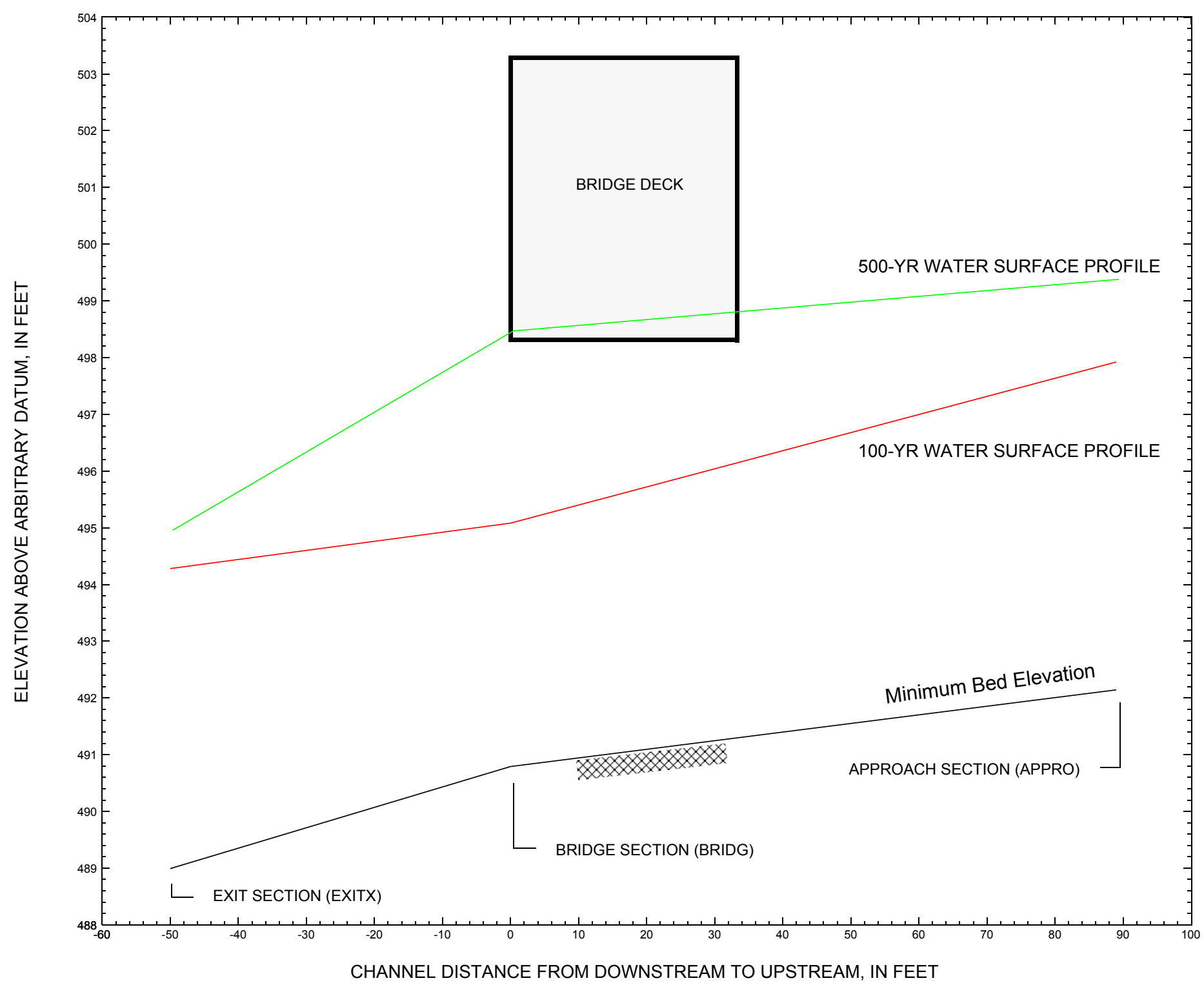

Figure 7. Water-surface profiles for the 100- and 500-yr discharges at structure JAY-VT02420009 on Vermont highway 242, crossing the Jay Branch of the Missisquoi River, Jay, Vermont. 


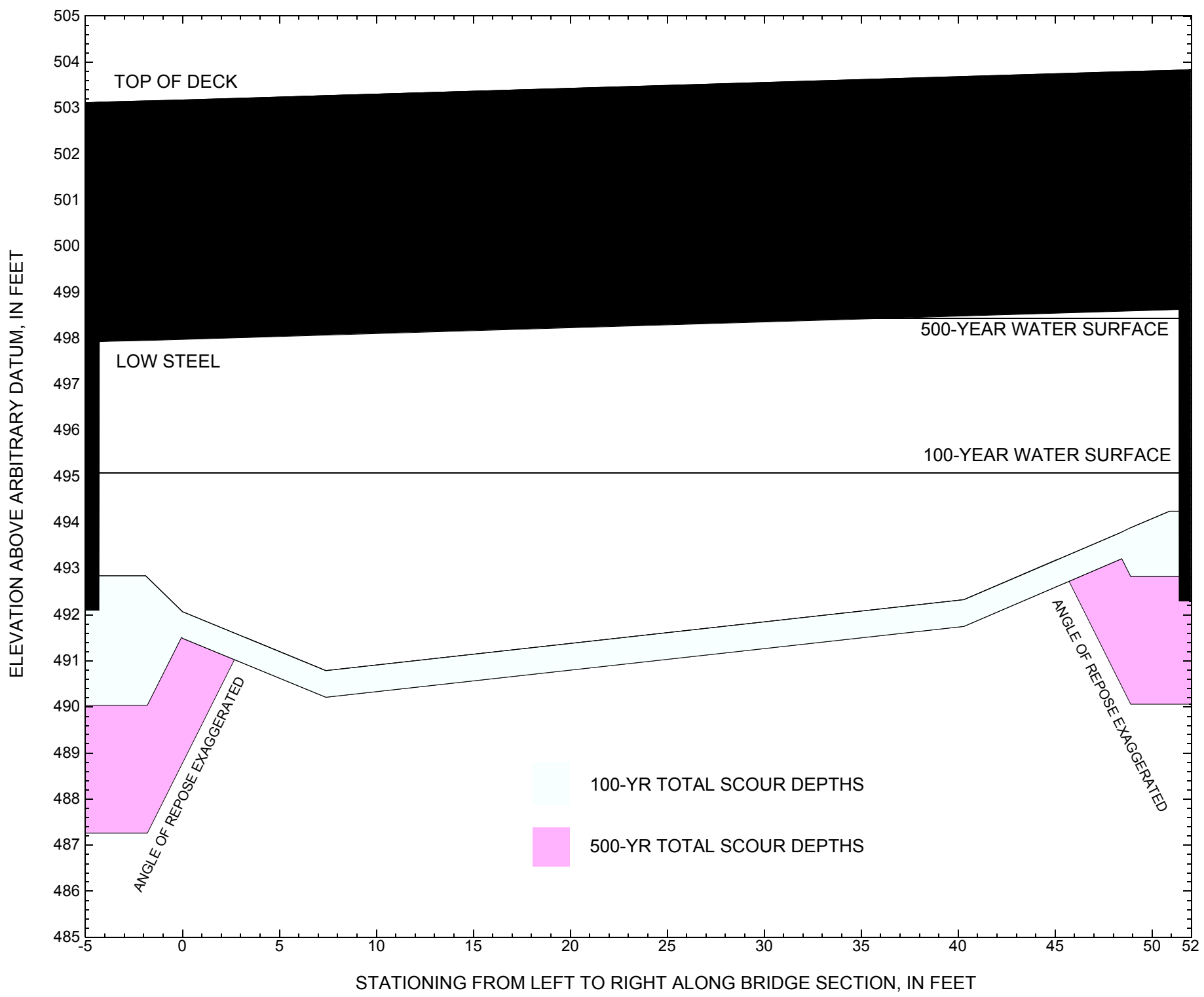

Figure 8. Scour elevations for the 100-yr and 500-yr discharges at structure JAY-VT02420009 on Vermont highway 242, crossing the Jay Branch of the Missisquoi River, Jay, Vermont. 
Table 1. Remaining footing/pile depth at abutments for the 100-year discharge at structure JAY-VT02420009 on Vermont highway 242 , crossing the Jay Branch of the Missisquoi River, Jay, Vermont.

[VTAOT, Vermont Agency of Transportation; --,no data]

\begin{tabular}{|c|c|c|c|c|c|c|c|c|c|c|c|}
\hline Description & Station $^{1}$ & $\begin{array}{l}\text { VTAOT } \\
\text { bridge } \\
\text { seat } \\
\text { elevation } \\
\text { (feet) }\end{array}$ & $\begin{array}{l}\text { Surveyed } \\
\text { minimum } \\
\text { low-chord } \\
\text { elevation }{ }^{2} \\
\text { (feet) }\end{array}$ & $\begin{array}{c}\text { Bottom of } \\
\text { footing } \\
\text { elevation } \\
\text { (feet) }\end{array}$ & $\begin{array}{l}\text { Channel } \\
\text { elevation at } \\
\text { abutment/ } \\
\text { pier }^{2} \\
\text { (feet) }\end{array}$ & $\begin{array}{l}\text { Contraction } \\
\text { scour depth } \\
\text { (feet) }\end{array}$ & $\begin{array}{l}\text { Abutment } \\
\text { scour } \\
\text { depth } \\
\text { (feet) }\end{array}$ & $\begin{array}{l}\text { Pier } \\
\text { scour } \\
\text { depth } \\
\text { (feet) }\end{array}$ & $\begin{array}{l}\text { Depth of } \\
\text { total scour } \\
\text { (feet) }\end{array}$ & $\begin{array}{c}\text { Elevation of } \\
\text { scour }^{2} \\
\text { (feet) }\end{array}$ & $\begin{array}{c}\text { Remaining } \\
\text { footing/pile } \\
\text { depth } \\
\text { (feet) }\end{array}$ \\
\hline \multicolumn{12}{|c|}{100 -yr. discharge is 1,110 cubic-feet per second } \\
\hline Left abutment & -3.8 & 101.70 & 497.74 & 492.1 & 492.9 & 0.6 & 2.2 & -- & 2.8 & 490.1 & -2.0 \\
\hline Right abutment & 50.9 & 101.88 & 498.87 & 492.3 & 494.3 & 0.6 & 0.8 & -- & 1.4 & 492.9 & 0.6 \\
\hline
\end{tabular}

1. Measured along the face of the most constricting side of the bridge.

2. Arbitrary datum for this study.

Table 2. Remaining footing/pile depth at abutments for the 500-year discharge at structure JAY-VT02420009 on Vermont highway 242, crossing the Jay Branch of the Missisquoi River, Jay, Vermont.

[VTAOT, Vermont Agency of Transportation; --, no data]

\begin{tabular}{|c|c|c|c|c|c|c|c|c|c|c|c|}
\hline Description & Station $^{1}$ & $\begin{array}{c}\text { VTAOT } \\
\text { bridge seat } \\
\text { elevation } \\
\text { (feet) }\end{array}$ & $\begin{array}{l}\text { Surveyed } \\
\text { minimum } \\
\text { low-chord } \\
\text { elevation }{ }^{2} \\
\text { (feet) }\end{array}$ & $\begin{array}{l}\text { Bottom of } \\
\text { footing } \\
\text { elevation } \\
\text { (feet) }\end{array}$ & $\begin{array}{l}\text { Channel } \\
\text { elevation at } \\
\text { abutment/ } \\
\text { pier }^{2} \\
\text { (feet) }\end{array}$ & $\begin{array}{l}\text { Contraction } \\
\text { scour depth } \\
\text { (feet) }\end{array}$ & $\begin{array}{c}\text { Abutment } \\
\text { scour } \\
\text { depth } \\
\text { (feet) }\end{array}$ & $\begin{array}{l}\text { Pier } \\
\text { scour } \\
\text { depth } \\
\text { (feet) }\end{array}$ & $\begin{array}{l}\text { Depth of } \\
\text { total scour } \\
\text { (feet) }\end{array}$ & $\begin{array}{c}\text { Elevation of } \\
\text { scour }^{2} \\
\text { (feet) }\end{array}$ & $\begin{array}{c}\text { Remaining } \\
\text { footing/pile } \\
\text { depth } \\
\text { (feet) }\end{array}$ \\
\hline \multicolumn{12}{|c|}{ 500-yr. discharge is 1,580 cubic-feet per second } \\
\hline Left abutment & -3.8 & 101.70 & 497.74 & 492.1 & 492.9 & 0.0 & 5.6 & -- & 5.6 & 487.3 & -4.8 \\
\hline Right abutment & 50.9 & 101.88 & 498.87 & 492.3 & 494.3 & 0.0 & 4.2 & -- & 4.2 & 490.1 & -2.2 \\
\hline
\end{tabular}

1. Measured along the face of the most constricting side of the bridge.

2. Arbitrary datum for this study. 


\section{SELECTED REFERENCES}

Arcement, G.J., Jr., and Schneider, V.R., 1989, Guide for selecting Manning's roughness coefficients for natural channels and flood plains: U.S. Geological Survey Water-Supply Paper 2339, 38 p.

Barnes, H.H., Jr., 1967, Roughness characteristics of natural channels: U.S. Geological Survey Water-Supply Paper 1849,213 p.

Benson, M. A., 1962, Factors Influencing the Occurrence of Floods in a Humid Region of Diverse Terrain: U.S. Geological Survey WaterSupply Paper 1580-B, 64 p.

Brown, S.A. and Clyde, E.S., 1989, Design of riprap revetment: Federal Highway Administration Hydraulic Engineering Circular No. 11, Publication FHWA-IP-89-016, 156 p.

Federal Highway Administration, 1983, Runoff estimates for small watersheds and development of sound design: Federal Highway Administration Report FHWA-RD-77-158

Froehlich, D.C., 1989, Local scour at bridge abutments in Ports, M.A., ed., Hydraulic Engineering--Proceedings of the 1989 National Conference on Hydraulic Engineering: New York, American Society of Civil Engineers, p. 13-18.

Hayes, D.C.,1993, Site selection and collection of bridge-scour data in Delaware, Maryland, and Virginia: U.S. Geological Survey WaterResources Investigation Report 93-4017, 23 p.

Interagency Advisory Committee on Water Data, 1982, Guidelines for determining flood flow frequency: U.S. Geological Survey, Bulletin 17B of the Hydrology Subcommittee, 190 p.

Johnson, C.G. and Tasker, G.D.,1974, Progress report on flood magnitude and frequency of Vermont streams: U.S. Geological Survey OpenFile Report 74-130, 37 p.

Lagasse, P.F., Schall, J.D., Johnson, F., Richardson, E.V., Chang, F., 1995, Stream Stability at Highway Structures: Federal Highway Administration Hydraulic Engineering Circular No. 20, Publication FHWA-IP-90-014, 144 p.

Laursen, E.M., 1960, Scour at bridge crossings: Journal of the Hydraulics Division, American Society of Civil Engineers, v. 86, no. HY2, p. 39-53.

Potter, W. D., 1957a, Peak rates of runoff in the Adirondack, White Mountains, and Maine woods area, Bureau of Public Roads

Potter, W. D., 1957b, Peak rates of runoff in the New England Hill and Lowland area, Bureau of Public Roads

Richardson, E.V. and Davis, S.R., 1995, Evaluating scour at bridges: Federal Highway Administration Hydraulic Engineering Circular No. 18, Publication FHWA-IP-90-017, 204 p.

Richardson, E.V., Simons, D.B., and Julien, P.Y., 1990, Highways in the river environment: Federal Highway Administration Publication FHWA-HI-90-016.

Ritter, D.F., 1984, Process Geomorphology: W.C. Brown Co., Debuque, Iowa, 603 p.

Shearman, J.O., 1990, User's manual for WSPRO--a computer model for water surface profile computations: Federal Highway Administration Publication FHWA-IP-89-027, 187 p.

Shearman, J.O., Kirby, W.H., Schneider, V.R., and Flippo, H.N., 1986, Bridge waterways analysis model; research report: Federal Highway Administration Publication FHWA-RD-86-108, 112 p.

Talbot, A.N., 1887, The determination of water-way for bridges and culverts.

U.S. Department of Transportation, 1993, Stream stability and scour at highway bridges, Participant Workbook: Federal Highway Administration Publication FHWA HI-91-011.

U.S. Geological Survey, 1986, North Troy, Vermont 7.5 Minute Series quadrangle map: U.S. Geological Survey Topographic Maps, Scale $1: 24,000$. 
APPENDIX A:

WSPRO INPUT FILE 


\section{WSPRO INPUT FILE}

T1 U.S. Geological Survey WSPRO Input File jay-009.wsp

T3

Q

SK

WS

*

J3

*

$\mathrm{XS}$

GR

GR

GR

$\mathrm{N}$

SA

*

XS

BR

GR

GR

N

CD

*

XR

GR

GR

*

*

* Changed to $-102.9,500.56$ based on same slope between -13 and 0 and photos

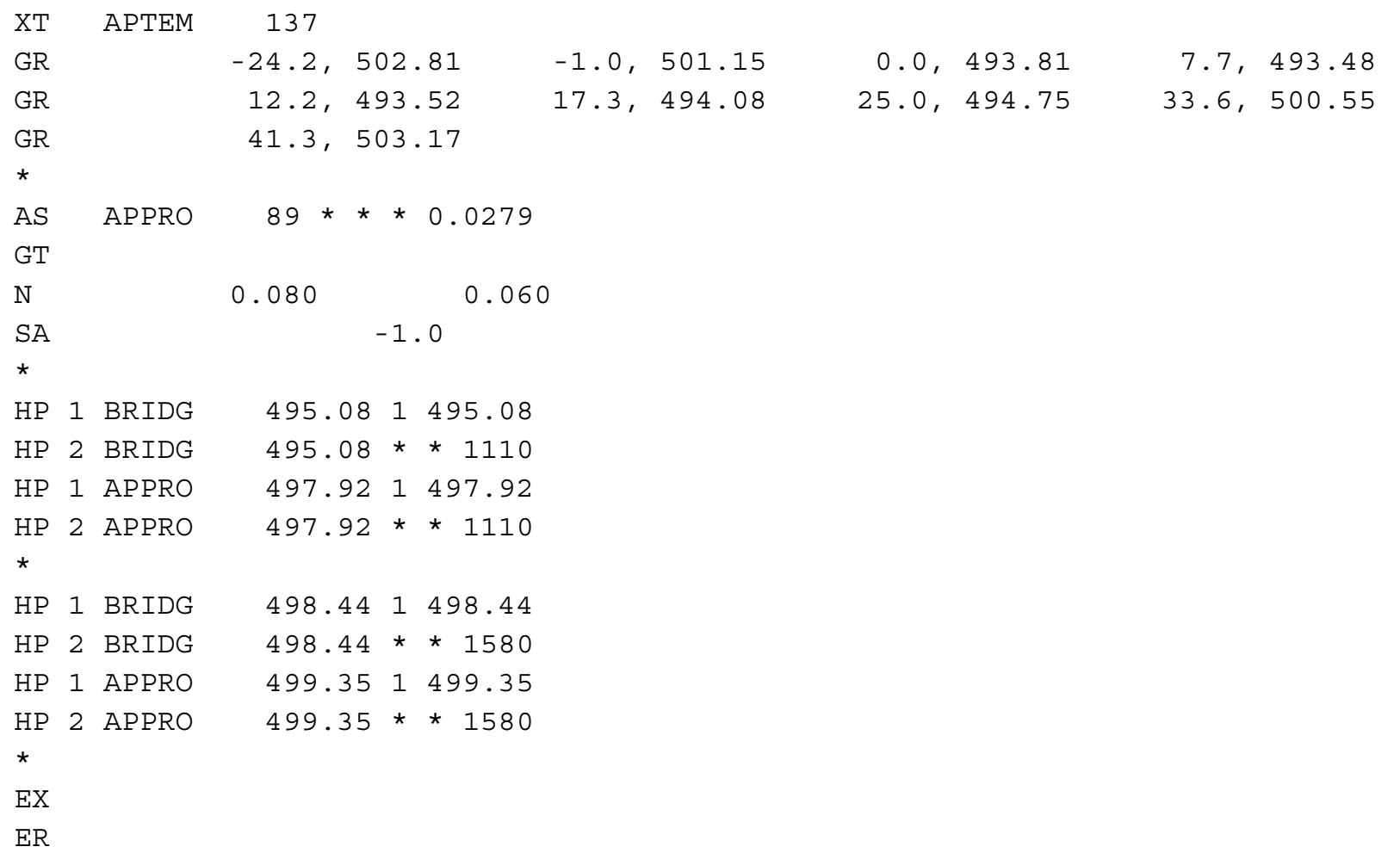




\section{APPENDIX B: \\ WSPRO OUTPUT FILE}




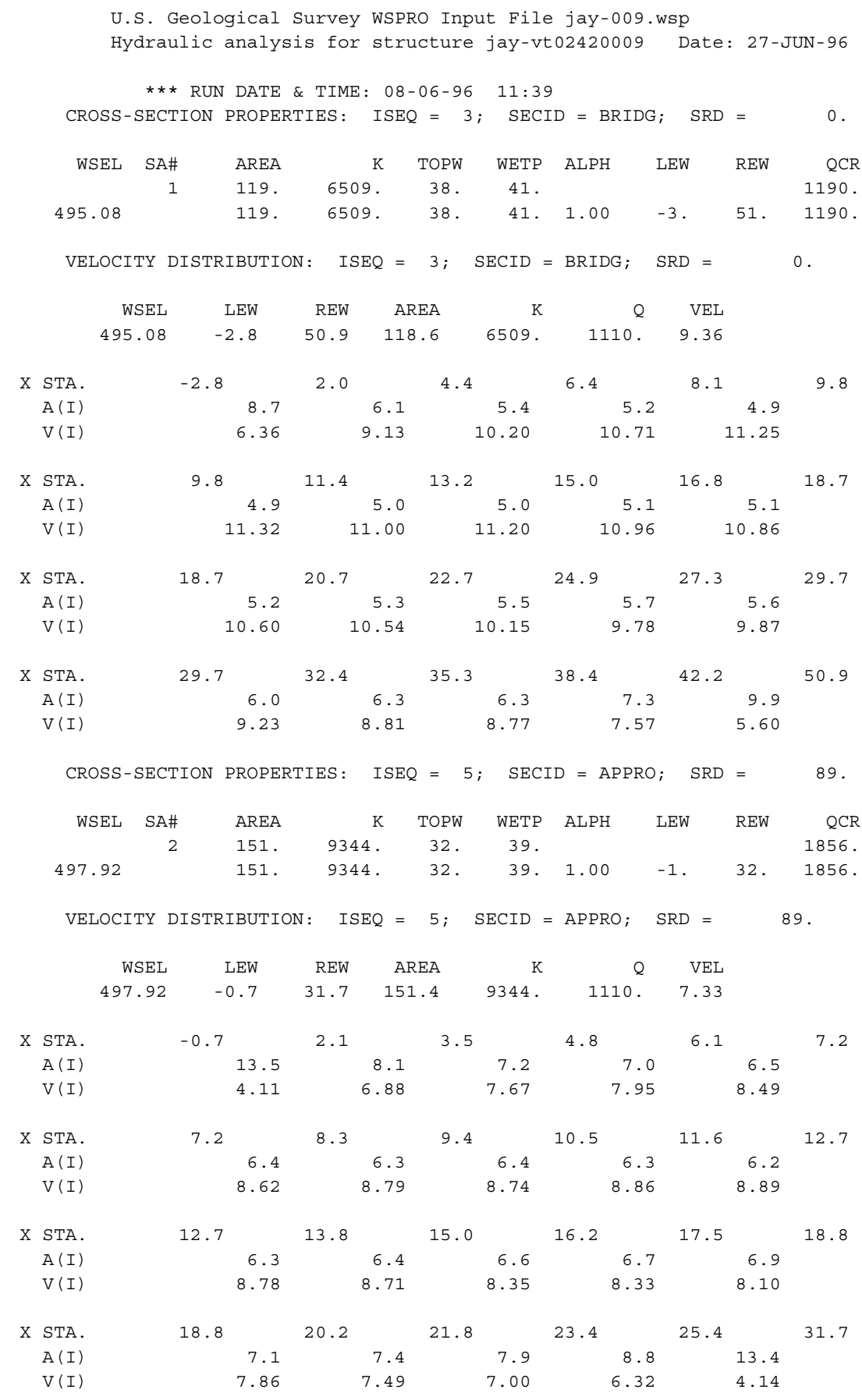




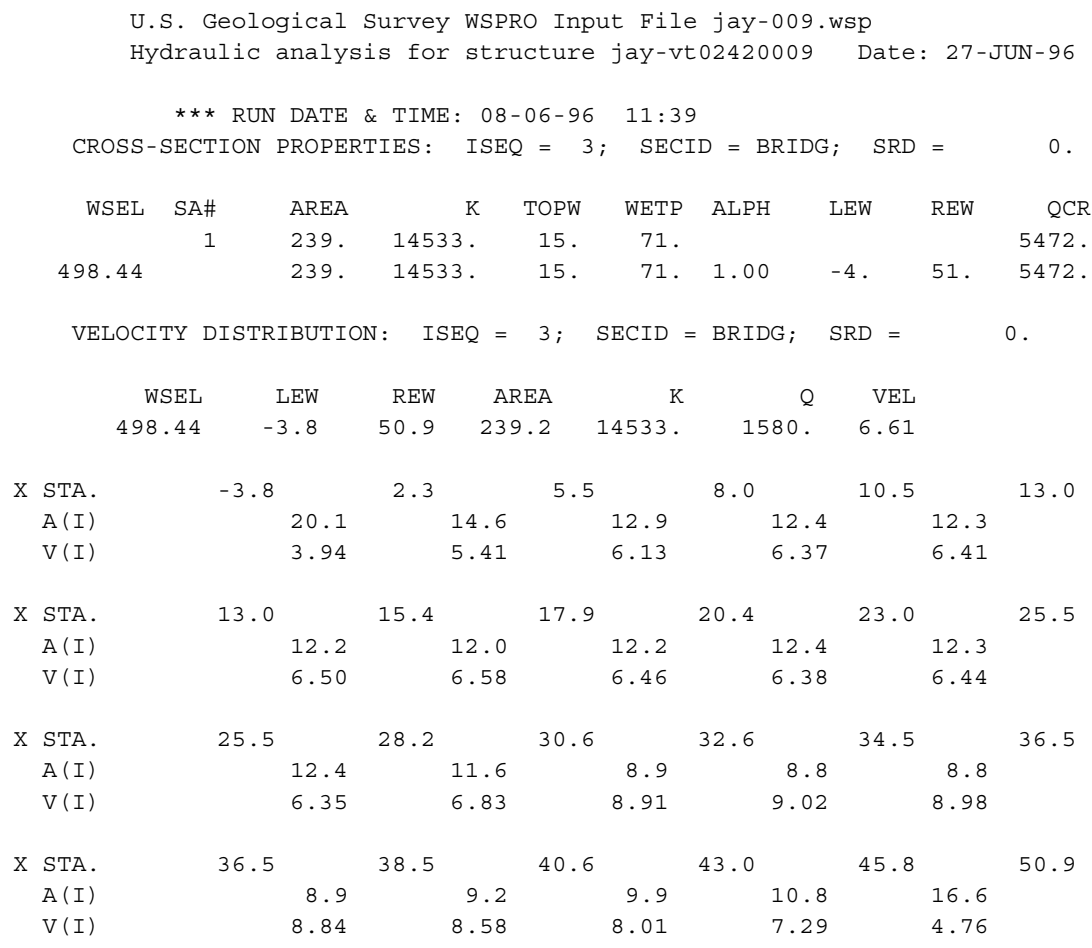

U.S. Geological Survey WSPRO Input File jay-009.wsp

Hydraulic analysis for structure jay-vt02420009 Date: 27-JUN-96

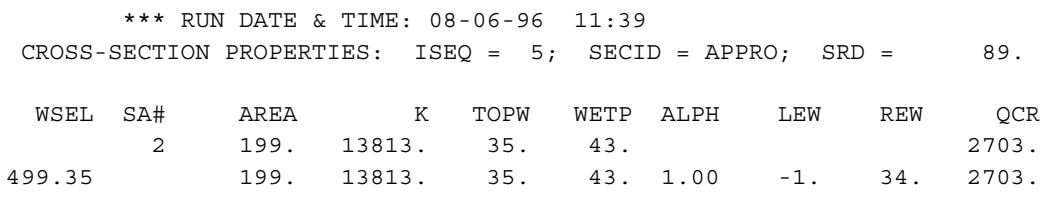

VELOCITY DISTRIBUTION: ISEQ $=5 ;$ SECID $=$ APPRO; $\quad$ SRD $=\quad 89$.

\begin{tabular}{|c|c|c|c|c|c|c|c|c|c|}
\hline & & WSEL & LEW & REW & AREA & K & $Q$ & VEL & \\
\hline & & 499.35 & -0.9 & 34.0 & 199.4 & 13813. & 1580. & 7.92 & \\
\hline $\mathrm{x}$ & STA. & & -0.9 & 2.2 & & 3.7 & 5.1 & 6.4 & 7.6 \\
\hline & $A(I)$ & & 18.3 & & 11.0 & 9.8 & 9.1 & 8.5 & \\
\hline & $V(I)$ & & 4.32 & & 7.21 & 8.09 & 8.68 & 9.28 & \\
\hline $\mathrm{x}$ & STA. & & 7.6 & 8.7 & & 9.9 & 11.0 & 12.1 & 13.3 \\
\hline & $A(I)$ & & 8.4 & & 8.2 & 8.2 & 8.0 & 8.2 & \\
\hline & $V(I)$ & & 9.45 & & 9.65 & 9.59 & 9.87 & 9.65 & \\
\hline $\mathrm{X}$ & STA. & & 13.3 & 14.5 & & 5.7 & 16.9 & 18.2 & 19.6 \\
\hline & $A(I)$ & & 8.1 & & 8.4 & 8.4 & 8.7 & 8.8 & \\
\hline & $V(I)$ & & 9.78 & & 9.36 & 9.40 & 9.12 & 9.01 & \\
\hline $\mathrm{X}$ & STA. & & 19.6 & 21.1 & & 2.6 & 24.3 & 26.4 & 34.0 \\
\hline & $A(I)$ & & 9.2 & & 9.5 & 10.4 & 11.8 & 18.5 & \\
\hline & $V(I)$ & & 8.55 & & 8.34 & 7.56 & 6.68 & 4.27 & \\
\hline
\end{tabular}




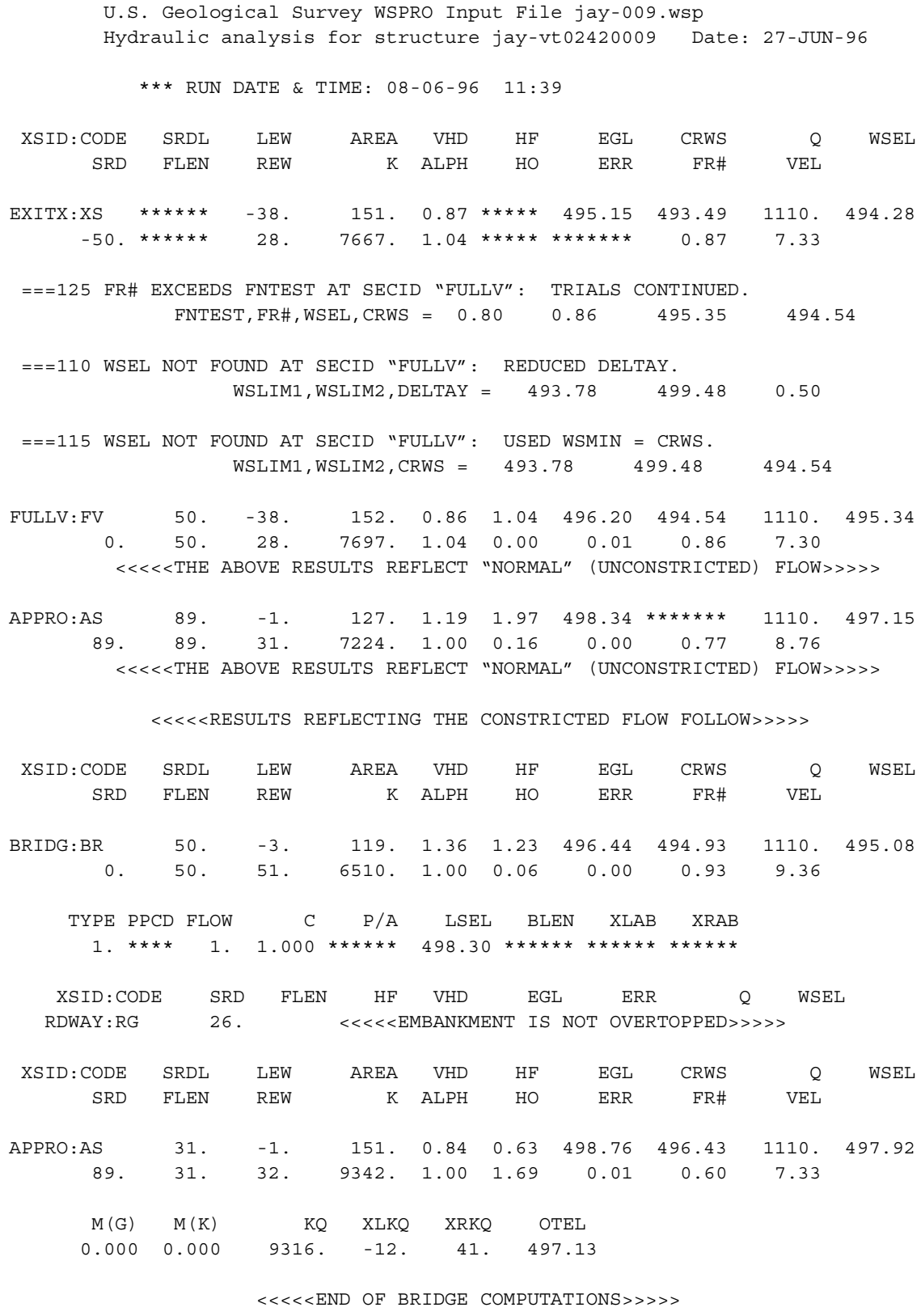


WSPRO OUTPUT FILE (continued)

FIRST USER DEFINED TABLE.

\begin{tabular}{|c|c|c|c|c|c|c|c|c|}
\hline XSID : CODE & SRD & LEW & REW & Q & $\mathrm{K}$ & AREA & VEL & WSEL \\
\hline EXITX:XS & -50 & -38 & 28. & 1110. & 7667. & 151. & 7.33 & 494.28 \\
\hline FULLV : FV & 0 . & -38 & 28 . & 1110. & 7697. & 152. & 7.30 & 495.34 \\
\hline BRIDG : BR & 0 . & -3 . & 51. & 1110. & 6510. & 119. & 9.36 & 495.08 \\
\hline RDWAY : RG & \multicolumn{3}{|c|}{$26 . * * * * * * * * * * * * * *$} & \multicolumn{3}{|c|}{$0 . * * * \star * * * * * * * * * * * * * * *$} & \multicolumn{2}{|c|}{$1.00 * \star * * * * * *$} \\
\hline APPRO : AS & 89. & -1 & 32 . & 1110. & 9342 . & 151. & 7.33 & 497.92 \\
\hline XSID : CODE & XLKQ & $\mathrm{XRKQ}$ & & & & & & \\
\hline APPRO: AS & -12 & 41. & 9316 & & & & & \\
\hline
\end{tabular}

SECOND USER DEFINED TABLE.

\begin{tabular}{|c|c|c|c|c|c|c|c|c|c|}
\hline XSID : CODE & CRWS & FR\# & YMIN & YMAX & $\mathrm{HF}$ & $\mathrm{HO}$ & VHD & EGL & WSEL \\
\hline EXITX:XS & 493.49 & 0.87 & 488.99 & 498.43 * & 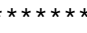 & 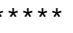 & 0.87 & 495.15 & 494.28 \\
\hline FULLV : FV & 494.54 & 0.86 & 490.04 & 499.48 & 1.04 & 0.00 & 0.86 & 496.20 & 495.34 \\
\hline BRIDG : BR & 494.93 & 0.93 & 490.79 & 498.87 & 1.23 & 0.06 & 1.36 & 496.44 & 495.08 \\
\hline RDWAY : RG & 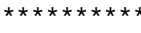 & $\star \star \star *$ & 500.56 & 503.95 * & $\star \star \star \star *$ & $\star \star \star \star$ & *** & $\approx \star \star$ & 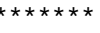 \\
\hline APPRO:AS & 496.43 & 0.60 & 492.14 & 501.83 & 0.63 & 1.69 & 0.84 & 498.76 & 497.92 \\
\hline
\end{tabular}

\footnotetext{
U.S. Geological Survey WSPRO Input File jay-009.wsp Hydraulic analysis for structure jay-vt02420009 Date: 27-JUN-96 *** RUN DATE \& TIME: 08-06-96 11:39 


\section{APPENDIX C:}

\section{BED-MATERIAL PARTICAL-SIZE DISTRIBUTION}




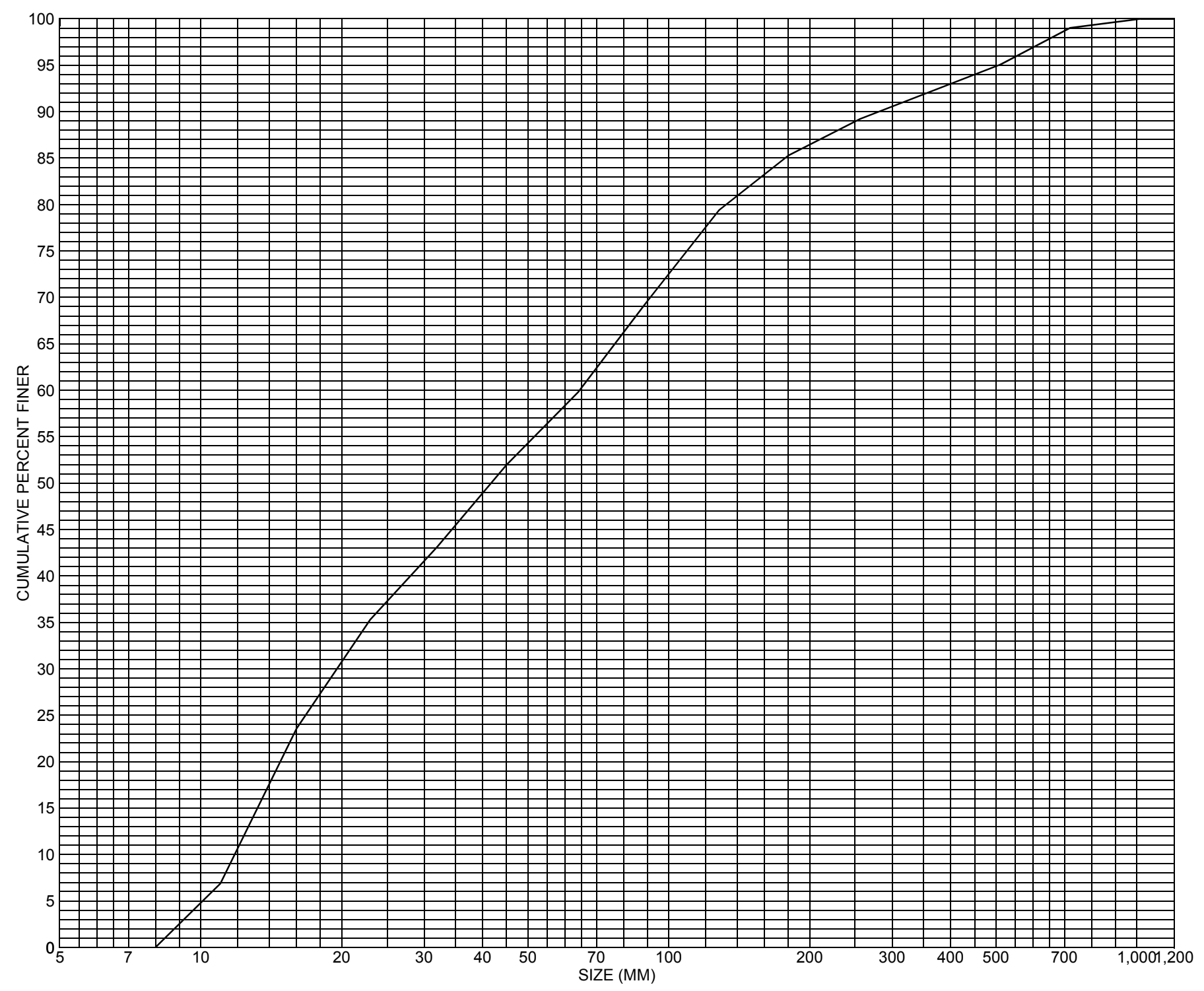

Appendix C. Bed material particle-size distribution for one pebble count transect at the approach cross-section for structure JAY-VT02420009 in Jay, Vermont. 


\section{APPENDIX D: \\ HISTORICAL DATA FORM}




\section{Structure Number JAY-VT02420009}

\section{General Location Descriptive}

Data collected by (First Initial, Full last name) $\underline{\text { L }}$. MEDALIE

Date $(M M / D D / Y Y) \_\mathbf{0 3} / \underline{\mathbf{0 6}} / \underline{\mathbf{9 6}}$

Highway District Number (I - 2; nn) $\mathbf{0 9}$

Town (FIPS place code; I - 4; nnnnn) $\mathbf{3 6 3 2 5}$

Waterway (I - 6) JAY BRANCH OF MISSISQUOI R.

Route Number VT242

Topographic Map North Troy

Latitude (I - 16; nnnn.n) $\mathbf{4 4 5 6 5}$
County (FIPS county code; I - 3; nnn)

Mile marker (I - 11; nnn.nnn) $\underline{\mathbf{0 0 2 2 2 0}}$

Road Name ( $I$ - 7):

Vicinity (I - 9) ML3.3 MI W JCT 101

Hydrologic Unit Code: $\underline{\mathbf{0 2 0 1 0 0 0 7}}$

Longitude (i - 17; nnnnn.n) $\mathbf{7 2 2 8 1}$

\section{Select Federal Inventory Codes}

FHWA Structure Number (I - 8) $\mathbf{2 0 0 2 7 8 0 0 0 9 1 0 1 2}$

Maintenance responsibility $(I-21 ; n n) \quad \mathbf{0 1}$

Year built (I - 27; YYYY) 1934

Average daily traffic, ADT (I - 29; nnnnnn) 000900

Year of ADT (I - 30; YY) $\mathbf{9 2}$

Opening skew to Roadway $(I-34 ; n n) \quad 45$

Operational status $(I-41 ; X) \mathbf{A}$

Structure type (I - 43; nnn) $\mathbf{3 0 2}$

Approach span structure type $(I-44 ; n n n)$ 000

Number of spans (I - 45; nnn) $\mathbf{0 0 1}$

Number of approach spans (I - 46; nnnn) $\mathbf{0 0 0 0}$

Comments:

The structural inspection report of 10/19/93 indicates the structure is a single span steel stringer type bridge. The downstream end of left abutment and the mid-section of the right abutment consists of older concrete. The right upstream wingwall has a small crack with minor spalling reported. The right abutment footing is not exposed. The left abutment footing, however, is exposed but is not undermined. The waterway takes a moderate turn into the structure. The streambed consists of cobbles and boulders with gravel deposits. There is streambed scour reported along the right abutment footing. The scour is about 3 feet below the top of the original footing and roughly a foot below the newer (Continued, page 31) 


\section{Bridge Hydrologic Data}

Is there hydrologic data available? $\mathbf{N}$ if No, type ctrl- $h \quad$ VTAOT Drainage area $\left(m i^{2}\right):$

Terrain character:

Stream character \& type: -

Streambed material: Boulders and coarse gravel

Discharge Data (cfs): $\quad \mathrm{Q}_{2.33}$

$$
\mathrm{Q}_{50}
$$

$\mathrm{Q}_{10}-$

$Q_{25}-$

Record flood date $(M M / D D / Y Y):-1 /$

Water surface elevation $(f t):-$

Estimated Discharge (cfs): Velocity at $\mathrm{Q}-$ $(\mathrm{ft} / \mathrm{s}):$

Ice conditions (Heavy, Moderate, Light) : -

Debris (Heavy, Moderate, Light):

The stage increases to maximum highwater elevation (Rapidly, Not rapidly):

The stream response is (Flashy, Not flashy):

Describe any significant site conditions upstream or downstream that may influence the stream's stage: -

Watershed storage area (in percent): - $\%$

The watershed storage area is: - (1-mainly at the headwaters; 2- uniformly distributed; 3-immediatly upstream oi the site)

Water Surface Elevation Estimates for Existing Structure:

\begin{tabular}{|l|l|l|l|l|l|}
\hline Peak discharge frequency & $Q_{2.33}$ & $Q_{10}$ & $Q_{25}$ & $Q_{50}$ & $Q_{100}$ \\
Water surface elevation (ft)) & - & - & - & - & - \\
Velocity $(\mathrm{ft} / \mathrm{sec})$ & - & - & - & - & - \\
\hline
\end{tabular}

Long term stream bed changes:

Is the roadway overtopped below the $\mathrm{Q}_{100}$ ? (Yes, No, Unknown): $\mathbf{U}$ Frequency: Relief Elevation (ft): Discharge over roadway at $Q_{100}\left(f^{3} / \mathrm{sec}\right)$ :

Are there other structures nearby? (Yes, No, Unknown): Upstream distance (miles): Town: If No or Unknown, type ctrl-n os Highway No. : Structure No. : Year Built:

Clear span (ft): Clear Height (ft): Full Waterway $\left(f^{2}\right)$ : 
Downstream distance (miles): Town: Year Built:

Highway No. : Structure No. : Structure Type:

Clear span $(f t):$ Clear Height (ft): Full Waterway $\left(f^{2}\right)$ :

Comments:

upstream section footing. There is large boulder riprap reported at all 4 corners of the structure. The structure has a history of overtopping but is reported in fairly good condition. The inspection report states that the channel scour is 3 to 4 feet deep along right abutment, but there has been no undermining. There is some apparent cobble aggradation on the left abutment side noted. No apparent settlement.

\section{USGS Watershed Data}

Watershed Hydrographic Data

Drainage area $(D A)$ 4.36 $\mathrm{mi}^{2}$

Watershed storage (ST) 0

Bridge site elevation 1266 $\mathrm{ft}$ $\%$

Main channel length 3.61 $\mathrm{mi}$

$10 \%$ channel length elevation 1319 $\mathrm{ft} \quad 85 \%$ channel length elevation 2185 $\mathrm{ft}$

Main channel slope $(S)$

(S) 320.33 $\mathrm{ft} / \mathrm{mi}$

Watershed Precipitation Data

Average site precipitation in Average headwater precipitation in

Maximum 2yr-24hr precipitation event $(124,2)$ in

Average seasonal snowfall (Sn) $\mathrm{ft}$ 


\section{Bridge Plan Data}

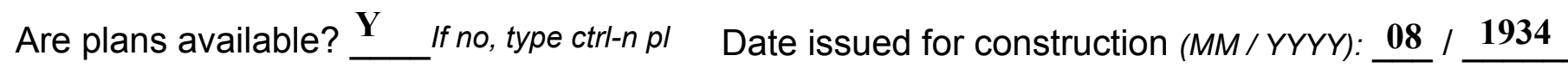
Project Number BP 1283-6613

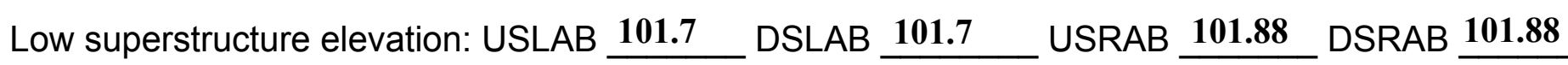
Benchmark location description:

BM \#1, spot on 10 foot boulder located about 150 feet left bankward from the left abutment on the roadway and 60 feet perpendicular to the roadway centerline, downstream (campground?), elevation 100.00

Reference Point (MSL, Arbitrary, Other): Arbitrary $\quad$ Datum (NAD27, NAD83, Other): Arbitrary Foundation Type: 1 (1-Spreadfooting; 2-Pile; 3- Gravity; 4-Unknown)

If 1: Footing Thickness $\mathbf{2 . 0} \quad$ Footing bottom elevation: $\mathbf{9 5 . 7 1}$

If 2: Pile Type: ___ (1-Wood; 2-Steel or metal; 3-Concrete) Approximate pile driven length: If 3: Footing bottom elevation: Is boring information available? $\mathbf{N}$ If no, type ctrl-n bi Number of borings taken: _Foundation Material Type: ____ (1-regolith, 2-bedrock, 3-unknown)

Briefly describe material at foundation bottom elevation or around piles:

Comments:

The bottom of footing elevation noted is an average of the bottom of left abutment. The minimum footing elevation indicated on the left is $\mathbf{9 5 . 6 0}$ and that on the right is $\mathbf{9 5 . 8 2}$. There is no hydraulic data on plans. The bridge was reconstructed in 1966 according to inventory codes, but no plans can be found. Plan data above refers to original structure design of 1934. Other elevation points: 1 . the top streamward edge of the upstream end left abutment where the slope begins to decline, elevation 105.03; 2 . at the same location described above on the upstream end of the right abutment, elevation 105.25. 


\section{Cross-sectional Data}

Is cross-sectional data available? $\underline{\mathbf{Y}}$ If no, type ctrl-n xs

Source (FEMA, VTAOT, Other)? VTAOT

Comments: There are several channel cross sections. No reproducible bridge cross sections.

\begin{tabular}{|l|l|l|l|l|l|l|l|l|l|l|l|}
\hline Station & - & - & - & - & - & - & - & - & - & - & - \\
\hline Feature & - & - & - & - & - & - & - & - & - & - & - \\
\hline $\begin{array}{l}\text { Low cord } \\
\text { elevation }\end{array}$ & - & - & - & - & - & - & - & - & - & - & - \\
\hline $\begin{array}{l}\text { Bed } \\
\text { elevation }\end{array}$ & - & - & - & - & - & - & - & - & - & - & - \\
\hline $\begin{array}{l}\text { Low cord to } \\
\text { bed length }\end{array}$ & - & - & - & - & - & - & - & - & - & - & - \\
\hline Station & - & - & - & - & - & - & - & - & - & - & - \\
\hline Feature & - & - & - & - & - & - & - & - & - & - & - \\
\hline $\begin{array}{l}\text { Low cord } \\
\text { elevation }\end{array}$ & - & - & - & - & - & - & - & - & - & - & - \\
\hline $\begin{array}{l}\text { Bed } \\
\text { elevation }\end{array}$ & - & - & - & - & - & - & - & - & - & - & - \\
\hline $\begin{array}{l}\text { Low cord to } \\
\text { bed length }\end{array}$ & - & - & - & - & - & - & - & - & - & - & - \\
\hline
\end{tabular}

Source (FEMA, VTAOT, Other)?

Comments: -

\begin{tabular}{|l|l|l|l|l|l|l|l|l|l|l|l|}
\hline Station & - & - & - & - & - & - & - & - & - & - & - \\
\hline Feature & - & - & - & - & - & - & - & - & - & - & - \\
\hline $\begin{array}{l}\text { Low cord } \\
\text { elevation }\end{array}$ & - & - & - & - & - & - & - & - & - & - & - \\
\hline $\begin{array}{l}\text { Bed } \\
\text { elevation }\end{array}$ & - & - & - & - & - & - & - & - & - & - & - \\
\hline $\begin{array}{l}\text { Low cord to } \\
\text { bed length }\end{array}$ & - & - & - & - & - & - & - & - & - & - & - \\
\hline Station & - & - & - & - & - & - & - & - & - & - & - \\
\hline Feature & - & - & - & - & - & - & - & - & - & - & - \\
\hline $\begin{array}{l}\text { Low cord } \\
\text { elevation }\end{array}$ & - & - & - & - & - & - & - & - & - & - & - \\
\hline $\begin{array}{l}\text { Bed } \\
\text { elevation }\end{array}$ & - & - & - & - & - & - & - & - & - & - & - \\
\hline $\begin{array}{l}\text { Low cord to } \\
\text { bed length }\end{array}$ & - & - & - & - & - & - & - & - & - & - & - \\
\hline
\end{tabular}




\section{APPENDIX E: \\ LEVEL I DATA FORM}


U. S. Geological Survey

Bridge Field Data Collection and Processing Form

Qa/Qc Check by: $\mathbf{E W}$ Date: $\underline{\mathbf{0 4} / 05 / 96}$

\section{Structure Number JAY-VT02420009} Computerized by: $\underline{\mathbf{E W} \text { Date: } 04 / 09 / 96}$

Reviewd by: $\quad$ RF Date: $\underline{\mathbf{0 6} / 27 / 96}$

\section{A. General Location Descriptive}

1. Data collected by (First Initial, Full last name) M. IVANOFF

2. Highway District Number 09

Mile marker $\mathbf{0 0 2 2 2 0}$

County 019 ORLEANS

Town JAY 36325

Waterway (I - 6) JAY BRANCH OF MISSISQUOI R.

Road Name ROUTE 242

Route Number VT242

Hydrologic Unit Code: $\mathbf{0 2 0 1 0 0 0 7}$

3. Descriptive comments:

3.3 MILES WEST OF JUNCTION WITH VT 101.

\section{B. Bridge Deck Observations}
4. Surface cover... LBUS 6
RBUS 5
LBDS 4
RBDS 6
Overall 6

(2b us,ds,lb,rb: 1- Urban; 2- Suburban; 3- Row crops; 4- Pasture; 5- Shrub- and brushland; 6- Forest; 7- Wetland)
5. Ambient water surface... US 2
UB 2
DS 2
(1- pool; 2- riffle)

6. Bridge structure type 1 (1- single span; 2- multiple span; 3- single arch; 4- multiple arch; 5-cylindrical culvert; 6- box culvert; or 7- other)
7. Bridge length 60
(feet)
Span length $\mathbf{5 5}$
(feet)
Bridge width $\underline{\mathbf{3 3 . 5}}$ (feet)

\section{Road approach to bridge:}
8. LB 0
RB 2
( 0 even, 1- lower, 2- higher)
9. LB
RB 1
(1- Paved, 2- Not paved)

10. Embankment slope (run / rise in feet / foot)

US left 3.1:1

US right 1.8:1

BUS

\begin{tabular}{|l|l|l|l|}
\hline \multicolumn{2}{|c|}{ Protection } & \multirow{2}{*}{ 13.Erosion } & 14.Severity \\
\cline { 1 - 1 } 11.Type & 12.Cond. & & \\
\hline
\end{tabular}

RBUS

RBDS

\begin{tabular}{l|l}
\hline 3 & \\
\hline 2 & \\
\hline 2 & \\
\hline
\end{tabular}

\begin{tabular}{l|}
\hline 1 \\
\hline 1 \\
\hline
\end{tabular}

\begin{tabular}{l}
\hline $\mathbf{0}$ \\
\hline $\mathbf{0}$ \\
\hline $\mathbf{0}$ \\
\hline
\end{tabular}

Bank protection types: 0- none; 1- < 12 inches,

2- < 36 inches; 3- $<48$ inches;

4- < 60 inches; 5- wall / artificial levee

Bank protection conditions: 1- good; 2- slumped;

3- eroded; 4- failed

Erosion: 0 - none; 1- channel erosion; 2 -

road wash; 3- both; 4- other

Erosion Severity: 0 - none; 1- slight; 2- moderate; 3- severe

\section{Channel approach to bridge (BF):}

15. Angle of approach: 15

16. Bridge skew: $\mathbf{6 0}$

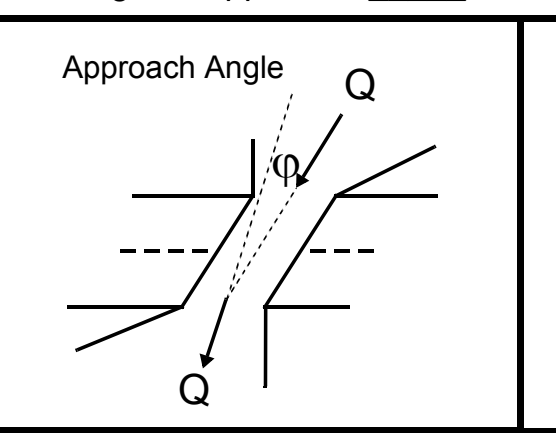

17. Channel impact zone 1 :

Where? LB $(L B, R B)$

Exist? $\mathbf{Y}(Y$ or $N)$ Bridge Skew Angle

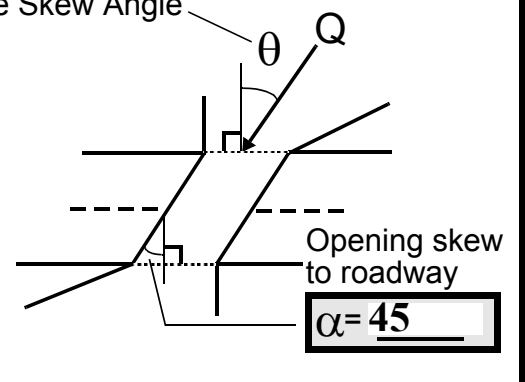

Range? 0 feet US

Severity 1

Channel impact zone 2:

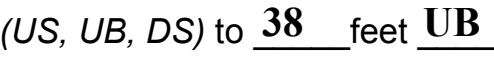

Where? $(L B, R B)$

Exist? $(Y$ or $N)$

Range? feet (US, UB, DS) to feet Impact Severity: 0- none to very slight; 1- Slight; 2- Moderate; 3- Severe 
18. Level II Bridge Type: $\underline{4,1 A}$

1a- Vertical abutments with wingwalls

1 b- Vertical abutments without wingwalls

2- Vertical abutments and wingwalls, sloping embankment

Wingwalls perpendicular to abut. face

3- Spill through abutments

4- Sloping embankment, vertical wingwalls and abutments

1a with wingwalls

Wingwall angle less than $90^{\circ}$.

19. Bridge Deck Comments (surface cover variations, measured bridge and span lengths, bridge type variations, approach overflow width, etc.)

\#4: RBUS road embankment for VT242 has a few trees and brush.

\#16: Abutments are skewed to the flow.

\section{Upstream Channel Assessment}

21. Bank height (BF) 22. Bank angle (BF)

20. SRD

LB

7.5

82.5

7.5

23. Bank width $\underline{\mathbf{5 5 . 0}} \quad$ 24. Channel width $\underline{\mathbf{3 5 . 0}}$
LB

RB

6.0
26. \% Veg. cover (BF) LB RB

3
1
27. Bank material (BF) LB 453
RB 453
28. Bank erosion (BF) $1 \quad 1$

25. Thalweg depth $\mathbf{3 4 . 5}$

29. Bed Material $\mathbf{4 5 3}$

30. Bank protection type: $\quad$ LB $\mathbf{3} \quad$ RB $\mathbf{3}$

SRD - Section ref. dist. to US face \% Vegetation (Veg) cover: 1- 0 to 25\%; 2- 26 to 50\%; 3- 51 to $75 \%$; 4- 76 to $100 \%$

Bed and bank Material: 0- organics; 1- silt / clay, <1/16mm; 2- sand, 1/16 - 2mm; 3- gravel, 2 - 64mm;

4- cobble, 64 - 256mm; 5- boulder, > 256mm; 6- bedrock; 7-manmade

Bank Erosion: 0- not evident; 1- light fluvial; 2- moderate fluvial; 3- heavy fluvial / mass wasting

Bank protection types: 0- absent; 1- < 12 inches; 2- < 36 inches; 3- < 48 inches; 4- < 60 inches; 5- wall / artificial levee

Bank protection conditions: 1- good; 2- slumped; 3- eroded; 4- failed

32. Comments (bank material variation, minor inflows, protection extent, etc.):

\#27/ \#29: Bank and bed material consists of cobble and boulder with gravel.

\#31: Left bank protection extends 100 feet from left abutment.

Right bank protection extends $>\mathbf{2 5 0}$ feet from right wingwall and road embankment 
36. Point bar extent: $\underline{\mathbf{1 6 0}}$ feet $\underline{\mathbf{U S}}$ (US, UB) to $\underline{\mathbf{2 8 0}}$ feet $\underline{\mathbf{U S}}$ (US, UB, DS) positioned $\underline{\mathbf{0}} \%$ LB to $\underline{\mathbf{5 0}} \%$ RB

37. Material: 453

38. Point or side bar comments (Circle Point or Side; Note additional bars, material variation, status, etc.):

Point bar

39. Is a cut-bank present? $\mathbf{Y}$ (Y or if $N$ type $c t r l-n c b)$

41. Mid-bank distance: 125

43. Bank damage: 1

42. Cut bank extent: 100 feet $\underline{\mathbf{U S}}$

(1- eroded and/or creep; 2- slip failure; 3- block failure)

44. Cut bank comments (eg. additional cut banks, protection condition, etc.):

Steep bank with exposure of cobble.

45. Is channel scour present? $\mathbf{N}$ ( $Y$ or if $N$ type ctrl-n cs)

47. Scour dimensions: Length -

Width -

Depth :-

46. Mid-scour distance: -

48. Scour comments (eg. additional scour areas, local scouring process, etc.):

NO CHANNEL SCOUR

49. Are there major confluences? $\mathbf{N}$

51. Confluence 1: Distance -

54. Confluence comments (eg. confluence name):

NO MAJOR CONFLUENCES
40. Where? $\underline{\mathbf{L B}}$ (LB or RB)

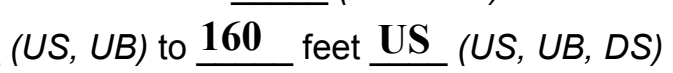

Position $\%$ LB to $\% \mathrm{RB}$ 
65. Debris and Ice Is there debris accumulation?

(Yor $N)$ 66. Where? $\mathbf{N}$

(1- Upstream; 2- At bridge; 3- Both)

67. Debris Potential ( 1- Low; 2- Moderate; 3- High)

68. Capture Efficiency 1 (1-Low; 2- Moderate; 3- High)

69. Is there evidence of ice build-up? 2

Ice Blockage Potential $\mathbf{N}$ (1-Low; 2- Moderate; 3- High)

70. Debris and Ice Comments:

1

\#67: The banks consist of large material with small trees on immediate bank.

\#68: Skewed bridge face with a low clearance (six feet).

\begin{tabular}{|l|c|c|c|c|c|c|c|c|}
\hline Abutments & $\begin{array}{c}71 . \text { Attack } \\
\angle \text { (BF) }\end{array}$ & $\begin{array}{c}72 \text {. Slope } \angle \\
\text { (Qmax) }\end{array}$ & $\begin{array}{c}\text { 73. Toe } \\
\text { loc. (BF) }\end{array}$ & $\begin{array}{c}\text { 74. Scour } \\
\text { Condition }\end{array}$ & $\begin{array}{c}75 . \text { Scour } \\
\text { depth }\end{array}$ & $\begin{array}{c}\text { 76. Exposure } \\
\text { depth }\end{array}$ & 77. Material & 78. Length \\
\hline LABUT & & $\mathbf{2 0}$ & $\mathbf{9 0}$ & $\mathbf{2}$ & $\mathbf{2}$ & $\mathbf{0}$ & $\mathbf{2 . 5}$ & $\mathbf{9 0 . 0}$ \\
\hline RABUT & $\mathbf{1}$ & - & $\mathbf{9 0}$ & & & $\mathbf{2}$ & $\mathbf{2}$ & $\mathbf{3 7 . 0}$ \\
\hline
\end{tabular}

Pushed: $L B$ or RB

Toe Location (Loc.): 0- even, 1- set back, 2- protrudes

Scour cond.: 0- not evident; 1- evident (comment); 2- footing exposed; 3-undermined footing; 4- piling exposed; 5- settled; 6- failed

Materials: 1- Concrete; 2- Stone masonry or drywall; 3- steel or metal; 4- wood

79. Abutment comments (eg. undermined penetration, unusual scour processes, debris, etc.):

0

1.5

1

80. Wingwalls:

Exist? Material? Scour Scour Exposure Angle? Length? Condition? depth? depth?

USLWW:

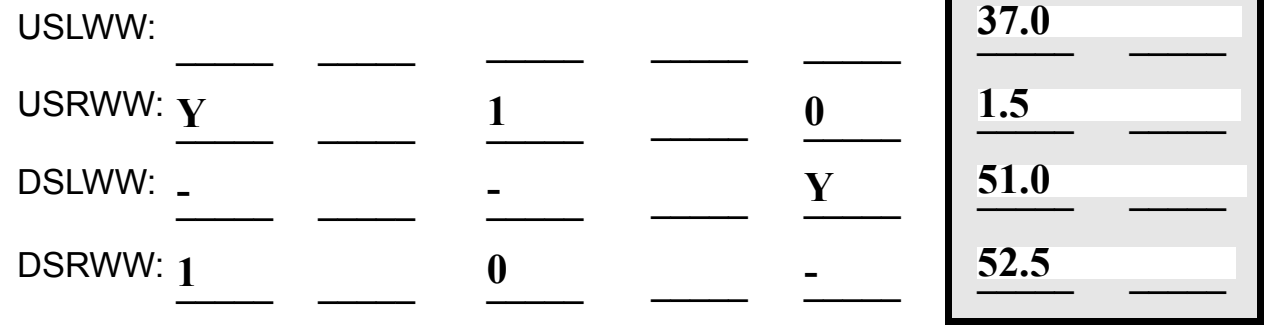

Wingwall materials: 1- Concrete; 2- Stone masonry or drywall; 3- steel or metal; 4- wood

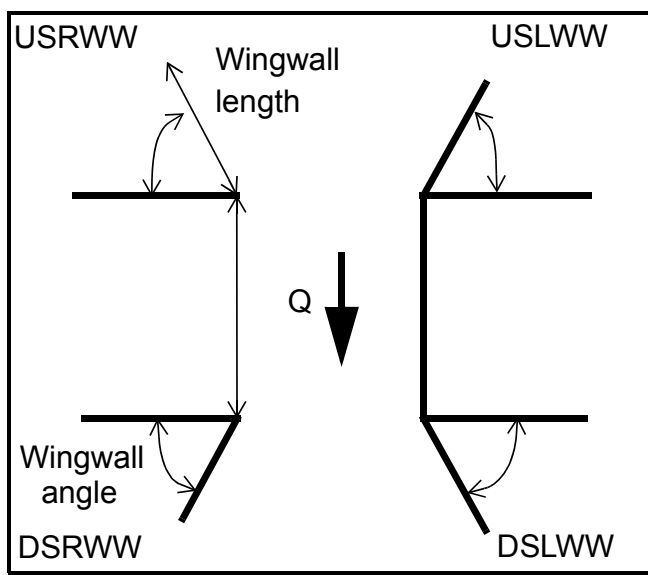

82. Bank / Bridge Protection:

\begin{tabular}{|l|l|l|l|l|l|l|l|c|}
\hline Location & USLWW & USRWW & LABUT & RABUT & LB & RB & DSLWW & DSRWW \\
\hline Type & - & $\mathbf{0}$ & $\mathbf{Y}$ & - & $\mathbf{1}$ & $\mathbf{1}$ & $\mathbf{1}$ & $\mathbf{1}$ \\
\hline Condition & $\mathbf{Y}$ & - & $\mathbf{1}$ & - & $\mathbf{1}$ & $\mathbf{2}$ & $\mathbf{4}$ & $\mathbf{2}$ \\
\hline Extent & $\mathbf{1}$ & - & $\mathbf{0}$ & $\mathbf{4}$ & $\mathbf{2}$ & $\mathbf{2}$ & $\mathbf{1}$ & - \\
\hline
\end{tabular}

Bank / Bridge protection types: 0- absent; 1- < 12 inches; 2- < 36 inches; 3- < 48 inches; 4- < 60 inches; 
83. Wingwall and protection comments (eg. undermined penetration, unusual scour processes, etc.):

-
-
-
-
-
2
1
1
2
1
1

Piers:

84. Are there piers? \#82 (Y or if $N$ type ctrl-n pr)

\begin{tabular}{|l|l|l|l|l|l|l|l|}
\hline \multirow{2}{*}{$\begin{array}{l}85 . \\
\text { Pier no. }\end{array}$} & \multicolumn{3}{|c|}{ width (w) feet } & \multicolumn{3}{c|}{ elevation (e) feet } \\
\cline { 2 - 9 } & w1 & w2 & w3 & e@w1 & e@w2 & e@w3 \\
\hline Pier 1 & $\mathbf{8 5 . 0}$ & $\mathbf{2 0 . 0}$ & $\mathbf{4 5 . 0}$ & $\mathbf{6 . 0}$ & $\mathbf{1 8 . 0}$ & $\mathbf{7 . 0}$ \\
\hline Pier 2 & $\mathbf{1 3 5 . 0}$ & - & - & $\mathbf{6 . 0}$ & - & - & - \\
\hline Pier 3 & - & - & - & - & - & - & w1 \\
\hline Pier 4 & - & - & - & - & - & w2 \\
\hline
\end{tabular}

\begin{tabular}{|l|l|l|l|l|}
\hline Level 1 Pier Descr. & \multicolumn{1}{|c|}{1} & \multicolumn{1}{|c|}{2} & \multicolumn{1}{|c|}{3} & \multicolumn{1}{|c|}{} \\
\hline 86. Location (BF) & $:$ & s at & foot- & N \\
\hline 87. Type & Spar & the & ing. & - \\
\hline 88. Material & se & US & & - \\
\hline 89. Shape & pro- & and & & - \\
\hline 90. Inclined? & tec- & DS & & - \\
\hline 91. Attack $\angle$ (BF) & tion & ends & & - \\
\hline 92. Pushed & alon & with & & - \\
\hline 93. Length (feet) & - & - & - & - \\
\hline 94. \# of piles & g left & none & & - \\
\hline 95. Cross-members & and & alon & & - \\
\hline 96. Scour Condition & right & g & & - \\
\hline 97. Scour depth & abut & expo & & - \\
\hline 98. Exposure depth & ment & sed & & - \\
\hline
\end{tabular}

LFP, LTB, LB, MCL, MCM, MCR, RB, RTB, RFP

1- Solid pier, 2- column, 3- bent

1-Wood; 2- concrete; 3- metal; 4- stone

1- Round; 2- Square; 3- Pointed

Y-yes; $N-$ no

$L B$ or $R B$

0- none; 1- laterals; 2- diagonals; 3- both

0- not evident; 1- evident (comment);

2- footing exposed; 3- piling exposed;

4- undermined footing; 5- settled; 6- failed 
99. Pier comments (eg. undermined penetration, protection and protection extent, unusual scour processes, etc.):

-
-
-
-
-
-
-
-
-
-

100.

\section{E. Downstream Channel Assessment}

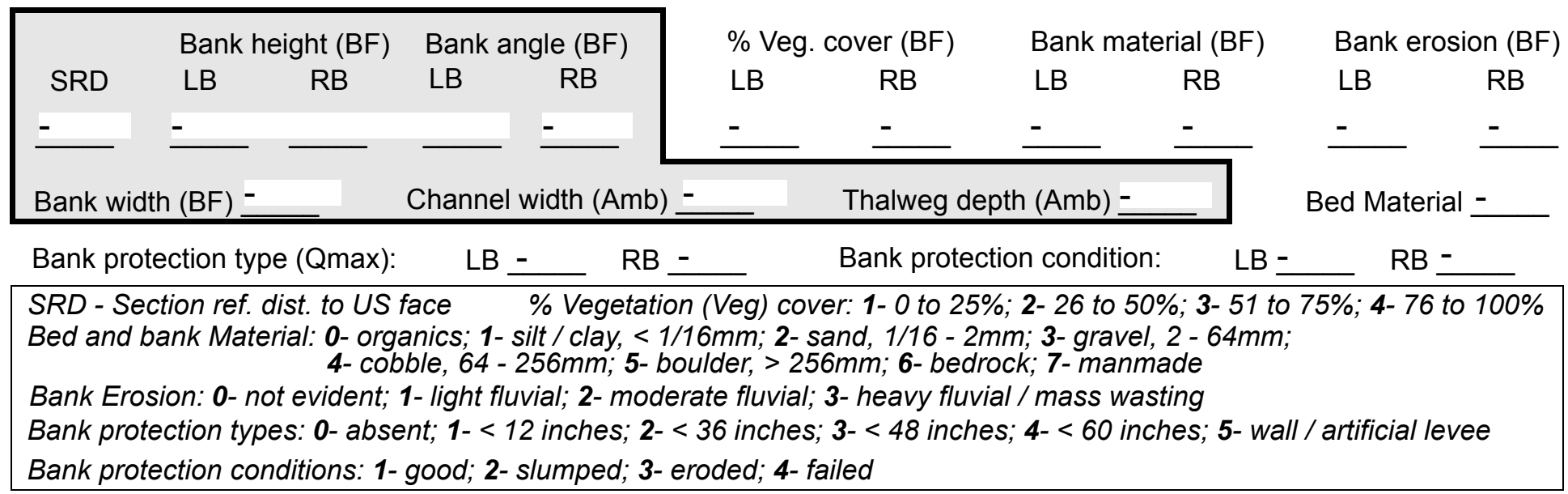

Comments (eg. bank material variation, minor inflows, protection extent, etc.):

-
-
-
-
-
-
-
-
-
-
-
-
-
-
-

101. Is a drop structure present? _ ( $Y$ or $N$, if $N$ type ctrl-n ds) 102. Distance: ___ feet

103. Drop:-_ feet 104. Structure material: NO (1- steel sheet pile; 2- wood pile; 3- concrete; 4- other) 105. Drop structure comments (eg. downstream scour depth):

PIERS 
Point bar extent: feet 1

(US, UB, DS) to 4 feet $\underline{543}$ (US, UB, DS) positioned $\mathbf{4 5 3}$ $\%$ LB to $\underline{\mathbf{0}} \%$ RB

Material: 1

Point or side bar comments (Circle Point or Side; note additional bars, material variation, status, etc.):

\section{3}

2

2

1

Is a cut-bank present? 1 (Yor if $N$ type ctrl-n $c b)$ Where? $\underline{\text { RB }}$ (LB or RB) Mid-bank distance: proCut bank extent: tec- feet tio (US, UB, DS) to $\underline{\mathbf{n} \quad \text { feet ext }}$ (US, UB, DS)

Bank damage: end (1- eroded and/or creep; 2- slip failure; 3- block failure)

Cut bank comments (eg. additional cut banks, protection condition, etc.):

s 70 feet from wingwall.

LB protection extends 70 feet from wingwall.

Is channel scour present? ( $Y$ or if $N$ type ctrl-n cs)

Mid-scour distance:

Scour dimensions: Length Width Depth:

Positioned $\%$ LB to $\% \mathrm{RB}$

Scour comments (eg. additional scour areas, local scouring process, etc.):

Are there major confluences? $\mathbf{N}$ ( $Y$ or if $N$ type ctrl-n $m c)$

Confluence 1: Distance NO

Confluence 2: Distance $\underline{\text { STR }}$ Enters on $\underline{\mathbf{D R}}$ ( $L B$ or RB)

Enters on $\underline{\mathbf{U C}}$ (LB or RB)

Confluence comments (eg. confluence name):

RE

\section{F. Geomorphic Channel Assessment}

107. Stage of reach evolution
1- Constructed

2- Stable

3- Aggraded

4- Degraded

5- Laterally unstable

6- Vertically and laterally unstable
How many? -

Type OP (1-perennial; 2- ephemeral)

Type TU (1-perennial; 2- ephemeral) 
108. Evolution comments (Channel evolution not considering bridge effects; See HEC-20, Figure 1 for geomorphic descriptors):

Y

O DS

10

0

US

30 DS

70100

34

Point bar starts beneath bridge at US end of right abutment and extends 80 feet. 


\begin{tabular}{|c|c|c|c|}
\hline & 109. & Plan View Sketch & \\
\hline $\begin{array}{l}\text { point bar } \\
\text { cut-bank } \\
\text { scour hole }\end{array}$ & debris & $\begin{array}{l}\text { flow } \stackrel{Q}{\text { cross-section }+1+1++} \\
\text { ambient channel }\end{array}$ & $\begin{array}{l}\text { stone wall } \square \square \square \square \\
\text { other wall } \square\end{array}$ \\
\hline
\end{tabular}


APPENDIX F:

SCOUR COMPUTATIONS 
SCOUR COMPUTATIONS

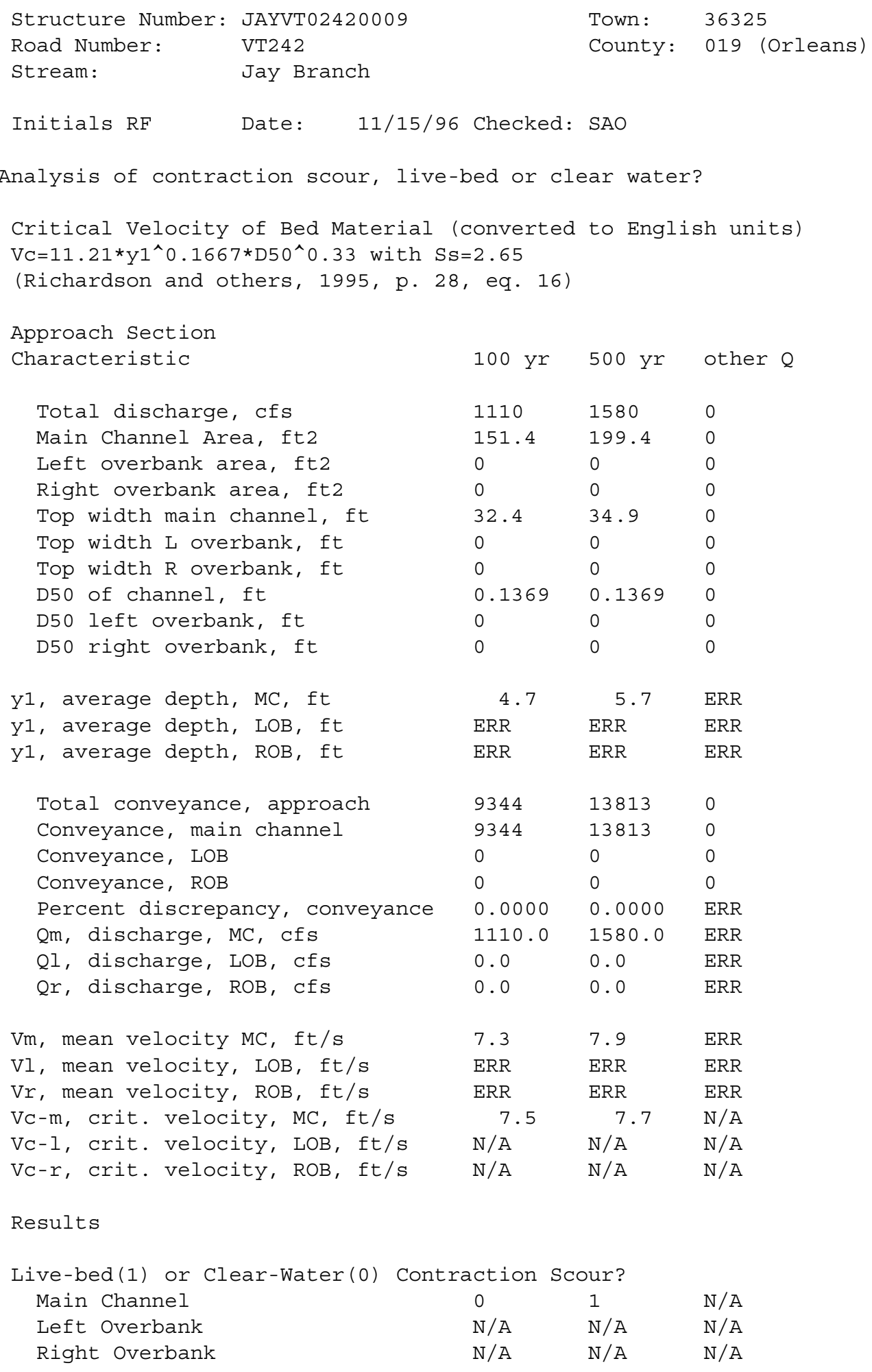




\begin{tabular}{|c|c|c|c|c|c|c|}
\hline \multicolumn{7}{|c|}{$\begin{array}{l}\text { Laursen's Live Bed Contraction Scour } \\
\mathrm{y} 2 / \mathrm{y} 1=(\mathrm{Q} 2 / \mathrm{Q} 1)^{\wedge}(6 / 7) *(\mathrm{~W} 1 / \mathrm{W} 2)^{\wedge}(\mathrm{k} 1) \\
\mathrm{ys}=\mathrm{y} 2-\mathrm{y} \text { bridge } \\
\text { (Richardson and others, 1995, p. } 30, \text { eq. } 17 \text { and } 18)\end{array}$} \\
\hline & Approach & & & Bridge & & \\
\hline Characteristic & $100 \mathrm{yr}$ & $500 \mathrm{yr}$ & Other Q & $100 \mathrm{yr}$ & $500 \mathrm{yr}$ & Other Q \\
\hline Q1, discharge, cfs & 1110 & 1580 & 0 & 1110 & 1580 & 0 \\
\hline Total conveyance & 9344 & 13813 & 0 & 6509 & 14533 & 0 \\
\hline Main channel conveyance & 9344 & 13813 & 0 & 6509 & 14533 & 0 \\
\hline Main channel discharge & 1110 & 1580 & ERR & 1110 & 1580 & ERR \\
\hline Area - main channel, ft2 & 151.4 & 199.4 & 0 & 119 & 239 & 0 \\
\hline (W1) channel width, ft & 32.4 & 34.9 & 0 & 38 & 38.7 & 0 \\
\hline (Wp) cumulative pier width, ft & 0 & 0 & 0 & 0 & 0 & 0 \\
\hline w1, adjusted bottom width(ft) & 32.4 & 34.9 & 0 & 38 & 38.7 & 0 \\
\hline D50, ft & 0.1369 & 0.1369 & 0.1369 & & & \\
\hline w, fall velocity, ft/s (p. 32) & $>2$ & $>2$ & 0 & & & \\
\hline Y, ave. depth flow, ft & 4.67 & 5.71 & N/A & 3.13 & 6.18 & ERR \\
\hline S1, slope EGL & 0.02404 & 0.02932 & $\begin{array}{l}0 \\
0\end{array}$ & & & \\
\hline $\begin{array}{l}\text { P, wetted perimeter, } \mathrm{MC} \text {, ft } \\
\text { R, hydraulic Radius, ft }\end{array}$ & $\begin{array}{l}39 \\
3.882\end{array}$ & $\begin{array}{l}43 \\
4.637\end{array}$ & $\begin{array}{l}0 \\
\text { ERR }\end{array}$ & & & \\
\hline $\mathrm{V}^{*}$, shear velocity, ft/s & 1.734 & 2.092 & $\mathrm{~N} / \mathrm{A}$ & & & \\
\hline $\mathrm{V} * / \mathrm{w}$ & $\mathrm{ERR}$ & ERR & ERR & & & \\
\hline $\begin{array}{l}\text { Bed transport coeff., } \mathrm{kl},(0.59 \text { if } \\
\mathrm{k} 1\end{array}$ & $\begin{array}{l}\mathrm{V} * / \mathrm{w}<0.5 \\
0.64\end{array}$ & $\begin{array}{l}0.64 \text { if } \\
0.64\end{array}$ & $\begin{array}{c}.5<\mathrm{V}^{*} / \mathrm{W}<2 \\
0\end{array}$ & ; 0.69 if & $\mathrm{V} * / \mathrm{w}>2.0$ & $0 \mathrm{p} .33)$ \\
\hline y2, depth in contraction, ft & 4.22 & 5.35 & ERR & & & \\
\hline $\begin{array}{l}\text { ys, scour depth, ft (y2-y_bridge) } \\
\text { ys, scour depth, ft (y2-yfullv) }\end{array}$ & $\begin{array}{l}1.09 \\
\mathrm{~N} / \mathrm{A}\end{array}$ & $\begin{array}{l}-0.83 \\
1.48\end{array}$ & $\begin{array}{l}\mathrm{N} / \mathrm{A} \\
\mathrm{N} / \mathrm{A}\end{array}$ & & & \\
\hline
\end{tabular}

Clear water Contraction Scour in MAIN CHANNEL

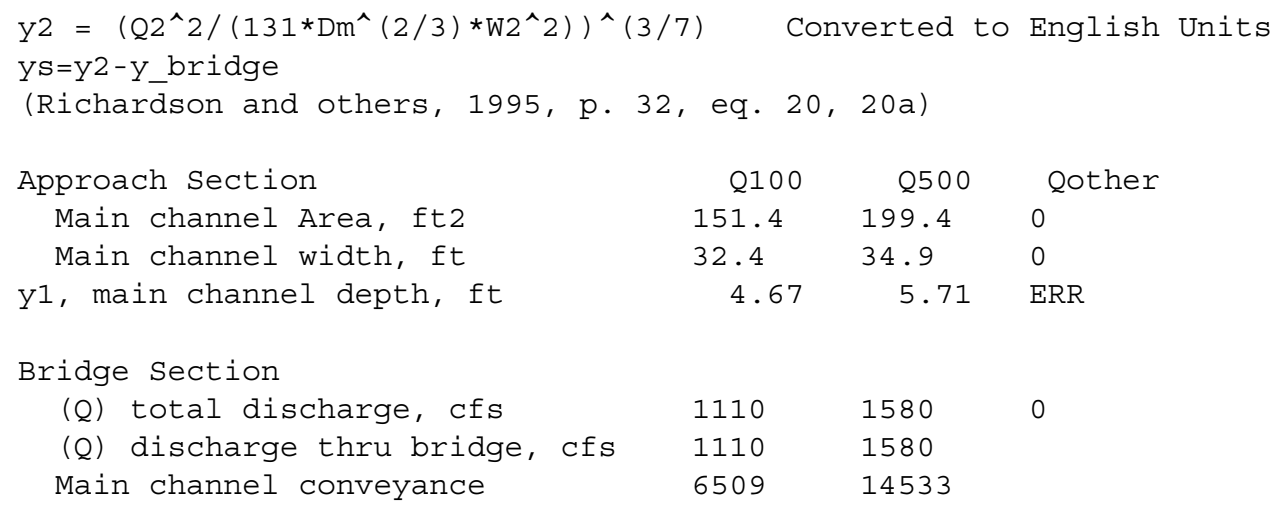




\begin{tabular}{|c|c|c|c|}
\hline Total conveyance & 6509 & 14533 & \\
\hline Q2, bridge MC discharge, cfs & 1110 & 1580 & $\mathrm{ERR}$ \\
\hline Main channel area, ft2 & 119 & 239 & 0 \\
\hline Main channel width (skewed), ft & 38.0 & 38.7 & 0.0 \\
\hline Cum. width of piers in MC, ft & 0.0 & 0.0 & 0.0 \\
\hline w, adjusted width, ft & 38 & 38.7 & 0 \\
\hline Y_bridge (avg. depth at br.), ft & 3.13 & 6.18 & $\mathrm{ERR}$ \\
\hline$\overline{\mathrm{Dm}}$, median $(1.25 * \mathrm{D} 50)$, ft & 0.171125 & 0.171125 & 0 \\
\hline $\mathrm{y}^{2}$, depth in contraction, ft & 3.70 & 4.93 & ERR \\
\hline epth & 57 & 1.2 & $\mathrm{~N} / \mathrm{A}$ \\
\hline
\end{tabular}

\begin{tabular}{|c|c|c|c|c|c|}
\hline \multicolumn{6}{|l|}{ ARMORING } \\
\hline D90 & & 0.9198 & 0.9198 & 0 & \multirow{5}{*}{$\mathrm{ERR}$} \\
\hline D95 & & 1.6602 & 1.6602 & 0 & \\
\hline Critical grain size,Dc, & ft & 0.6313 & 0.2270 & \multirow{3}{*}{$\begin{array}{l}0 \\
\text { ERR }\end{array}$} & \\
\hline Decimal-percent coarser & than DC & 0.13963 & 0.37954 & & \\
\hline depth to armoring, ft & & 11.67 & 1.11 & & \\
\hline Pressure Flow Scour (con & traction sco & ur for or: & ifice flor & ERR & itions) \\
\hline $\mathrm{Hb}+\mathrm{Ys}=\mathrm{Cq}{ }^{*} \mathrm{qb} r / \mathrm{Vc}$ & $\mathrm{Cq}=1 / \mathrm{Cf} * \mathrm{CC}$ & & $C f=1.5 * F$ & $r^{\wedge} 0.43$ & $(<=1)$ \\
\hline Chang Equation & $\mathrm{CC}=\mathrm{SQRT}[0.1$ & $0(\mathrm{Hb} /(\mathrm{ya}-\mathrm{r}$ & w) -0.56$)]$ & +0.79 & $(<=1)$ \\
\hline
\end{tabular}

\begin{tabular}{|c|c|c|c|}
\hline & Q100 & Q500 & OtherQ \\
\hline Q, total, cfs & 1110 & 1580 & 0 \\
\hline Q, thru bridge, cfs & 1110 & 1580 & 0 \\
\hline Total Conveyance, bridge & 6509 & 14533 & 0 \\
\hline Main channel (MC) conveyance, bridge & 6509 & 14533 & 0 \\
\hline Q, thru bridge $M C$, Cfs & 1110 & 1580 & $\mathrm{ERR}$ \\
\hline Vc, critical velocity, ft/s & 7.47 & 7.72 & $\mathrm{~N} / \mathrm{A}$ \\
\hline Vc, critical velocity, m/s & 2.28 & 2.35 & $\mathrm{~N} / \mathrm{A}$ \\
\hline Main channel width (skewed), ft & 38.0 & 38.7 & 0.0 \\
\hline Cum. width of piers in MC, ft & 0.0 & 0.0 & 0.0 \\
\hline w, adjusted width, ft & 38.0 & 38.7 & 0.0 \\
\hline qbr, unit discharge, $f t^{\wedge} 2 / \mathrm{s}$ & 29.2 & 40.8 & $\mathrm{ERR}$ \\
\hline qbr, unit discharge, $\mathrm{m}^{\wedge} 2 / \mathrm{s}$ & 2.7 & 3.8 & $\mathrm{~N} / \mathrm{A}$ \\
\hline Area of full opening, $\mathrm{ft}^{\wedge} 2$ & 119.0 & 239.0 & 0.0 \\
\hline $\mathrm{Hb}$, depth of full opening, ft & 3.13 & 6.18 & ERR \\
\hline $\mathrm{Hb}$, depth of full opening, $m$ & 0.95 & 1.88 & $\mathrm{~N} / \mathrm{A}$ \\
\hline Fr, Froude number, bridge MC & 0.93 & 0.56 & 0 \\
\hline Cf, Fr correction factor $(<=1.0)$ & 1.00 & 1.00 & 0.00 \\
\hline Elevation of Low Steel, ft & 0 & 498.301 & 0 \\
\hline Elevation of Bed, ft & -3.13 & 492.13 & $\mathrm{~N} / \mathrm{A}$ \\
\hline Elevation of Approach, ft & 0 & 499.35 & 0 \\
\hline Friction loss, approach, ft & 0 & 0.38 & 0 \\
\hline Elevation of WS immediately US, ft & 0.00 & 498.97 & 0.00 \\
\hline ya, depth immediately US, ft & 3.13 & 6.84 & $\mathrm{~N} / \mathrm{A}$ \\
\hline ya, depth immediately US, m & 0.95 & 2.09 & $\mathrm{~N} / \mathrm{A}$ \\
\hline Mean elevation of deck, ft & 0 & 503.478 & 0 \\
\hline $\mathrm{w}$, depth of overflow, ft $(>=0)$ & 0.00 & 0.00 & 0.00 \\
\hline Cc, vert contrac correction $(<=1.0)$ & 1.00 & 0.98 & ERR \\
\hline Ys, depth of scour, ft & 0.00 & -0.76 & 0.00 \\
\hline
\end{tabular}




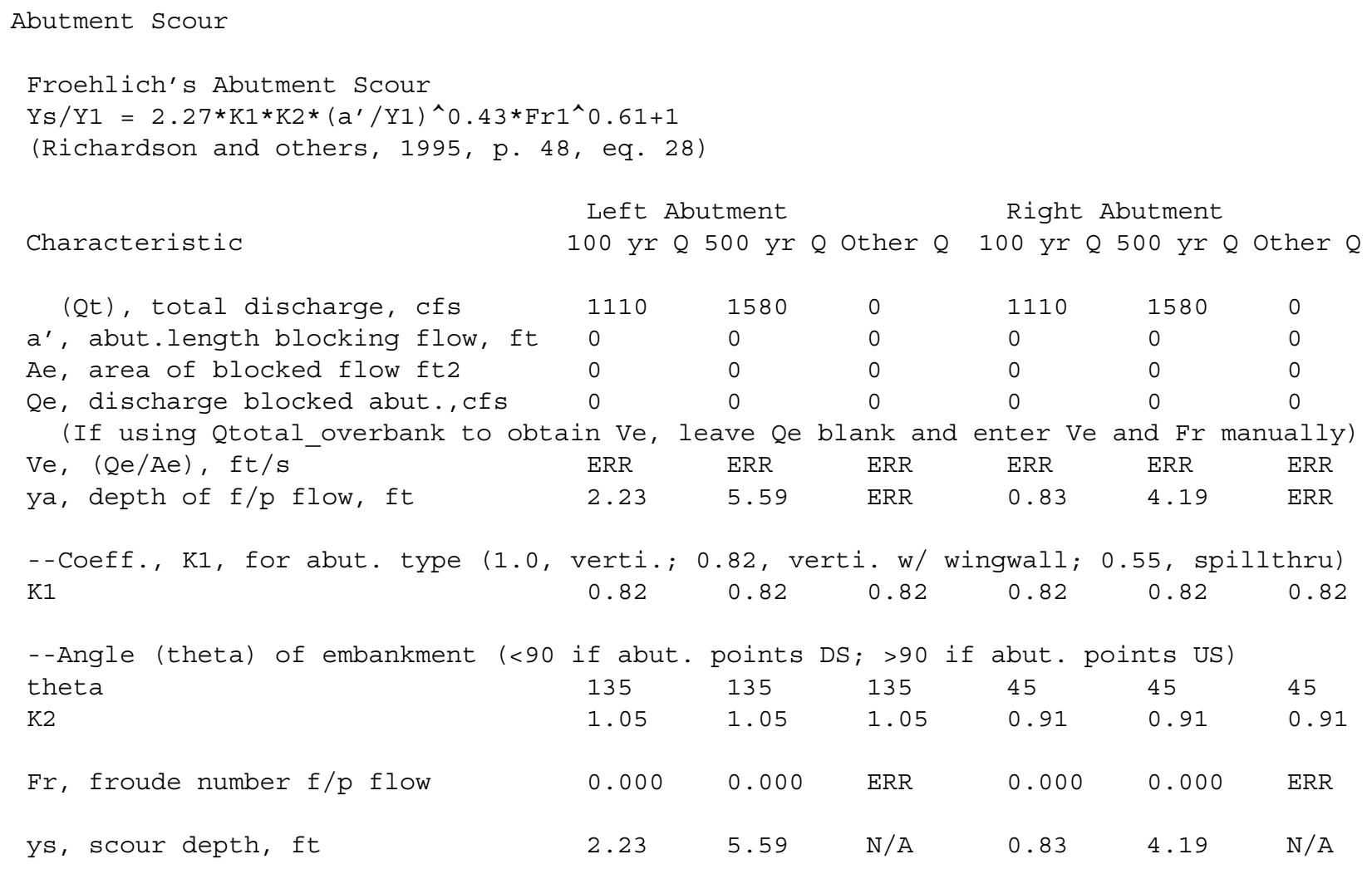




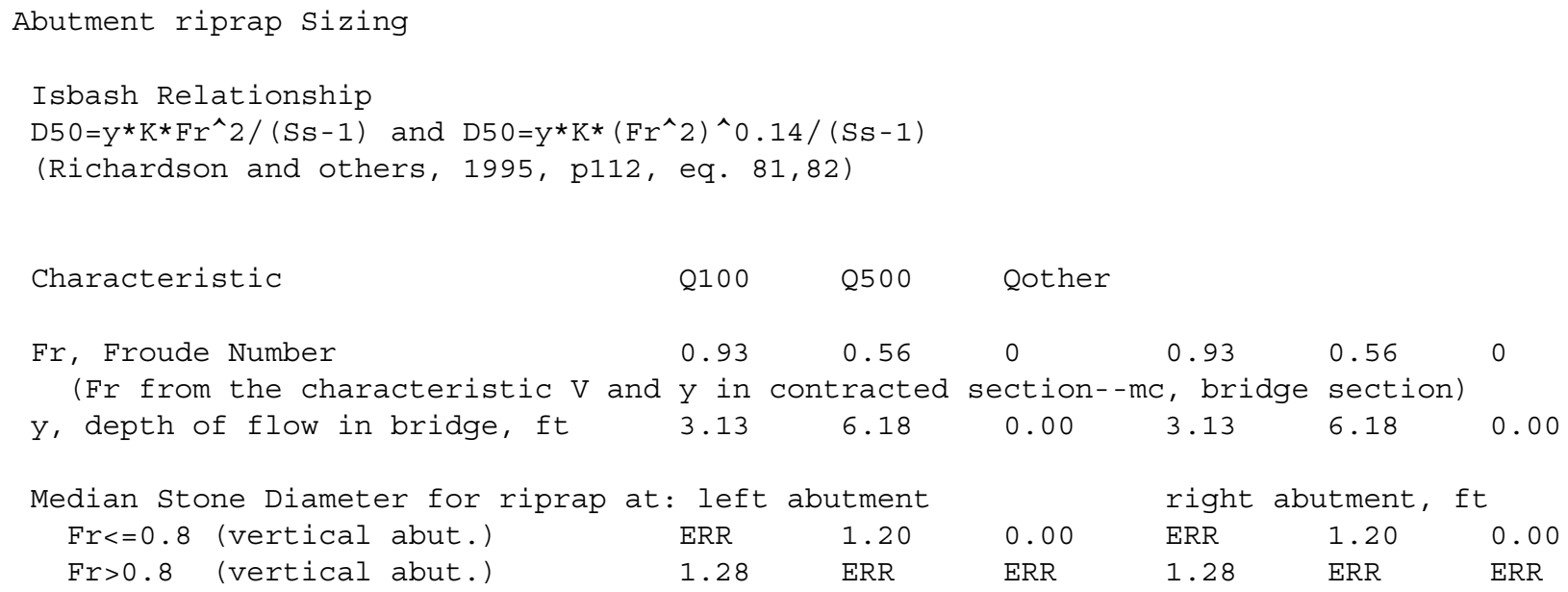

